\title{
SPROGFORSKEREN HOLGER PEDERSENS IRSKE REJSEBREVE
}

\author{
$\mathrm{AF}$
}

\section{Ruth Bentzen}

$\mathrm{B}$ landt sprogforskeren Holger Pedersens papirer ${ }^{1}$ ) giver de breve, han skrev under sin store udenlandsrejse I $892-96$ til J. L. Ussing, et indblik $\mathrm{i}$ hans daglige arbejde og oplevelser. I de I I, han skrev under sit 5 måneders ophold $\mathrm{i}$ Irland, får vi et farverigt billede af Holger Pedersens møde med Irland og irerne. Holger Pedersen indsamlede her det sproglige materiale, som han senere brugte ved udarbejdelsen af sine betydningsfulde arbejder om keltisk sprog. Først $0 \mathrm{~g}$ fremmest disputatsen om Aspirationen i Irsk ( 1897 ) og senere det monumentale værk Vergleichende Grammatik der keltischen Sprachen (1909-I3).

Holger Pedersen blev født den 7. april 1867 i Gjelballe ved Kolding. Efter endt skolegang i Ribe, hvortil familien var flyttet efter faderens død i 1877 , begyndte han at studere ved Københavns Universitet, og i sommeren 1890 tog han skoleembedsexamen i klassisk filologi og dansk. Efter embedsexamen påbegyndte han studiet af sammenlignende indoeuropæisk sprogvidenskab. I 1892 satte en række rejsestipendier ham i stand til at foretage en større udenlandsrejse, der skulle komme til at vare 4 år. Efter et kortere ophold i Italien for, som han selv siger, at skaffe sig praktisk øvelse $\mathrm{i}$ italiensk ${ }^{2}$ ) tog han til Leipzig, hvor han studerede hos Karl Brugmann, professor $\mathrm{i}$ indogermansk sprogvidenskab $\left.^{3}\right)$, og A. Leskien, professor i slavisk ${ }^{4}$ ). Et resultat af opholdet i Leipzig var afhandlingen Das indogermanische $\mathrm{s}$ im Slavischen ${ }^{5}$ ). Hen på foråret $\mathrm{I} 893$ forlod han Leipzig og tilbragte hele sommeren på Corfu og i Epirus med „førstehånds studier av albanesisk "6). Efter et studieophold i Berlin på 2 semestre afbrudt af et kortere ophold i Moskva i „Påskeferien“ mellem semestrene rejste han i oktober 1894 til Greifswald for at studere keltisk hos professor $\mathrm{H}$. Zimmer, der i i88 I var 
blevet udnævnt til professor i sanskrit og indoeuropæisk sprogvidenskab her. Hans videnskabelige virke udfoldede sig "paa det germanistiske, indiske og keltiske Omraade, men det er dog særlig som Keltolog, at Z. har vundet Navn, og hans Undersøgelser paa dette Omraade kan betragtes som banebrydende" som Holger Pedersen senere skrev om sin tidligere lærer i keltisk ${ }^{7}$ ). De semestre, Holger Pedersen tilbragte i Greifswald, var meget udbytterige. Professor Zimmers undervisning gik efter Holger Pedersens eget udsagn langt ud over den officielle ramme ${ }^{8}$ ). For at uddybe sine studier af keltisk drog Holger Pedersen så i august I 895 til Irland, hvor han tilbragte de næste 5 måneder dels i Dublin, dels på Aranøerne. Fra dette ophold kan hans daglige arbejde følges dels gennem hans optegnelser og dels gennem de breve, han i disse måneder skrev til professor Ussing. Han afsluttede denne store udenlandsrejse med endnu et semester i Greifswald. Efter hjemkomsten, i slutningen af juli 1896 , udmøntede han sine keltiske studier i afhandlingen Aspirationen i Irsk, som han den 24. juni 1897 forsvarede for doktorgraden.

Modtageren af Holger Pedersens breve var hans lærer, professor i klassisk filologi og arkæologi Johan Louis Ussing (1820-1905). Efter studenterexamen i 1836 begyndte han filologiske studier ved Københavns Universitet. Blandt hans lærere var J. N. Madvig (1804-r8g6), der fik ham til i særlig grad at interessere sig for klassisk arkæologi; dette resulterede i magisterafhandlingen fra 1844: De nominibus vasorum Græcorum. Også Ussing foretog efter endt embedsexamen en længere udenlandsrejse. Den gik til Italien og Grækenland, specielt Thessalien. Resultatet af denne rejse var rejseskildringen: Rejsebilleder fra Syden ( 1847 ) og de to afhandlinger: Inscriptiones Græcæ ineditæ ( 1847 ) og De Parthenone ejusque partibus (I849). I I 847 blev han lektor i græsk og latinsk filologi og arkæologi og to år senere professor i samme fag, først som extraordinær og fra $185^{\circ}$ som ordinær professor. Ved siden af professoratet bestred han flere andre poster f.ex. som efor for Elers' Kollegium ( $1874-93$ ) og som regensprovst ( $1876-96$ ). Som 75 -årig blev Ussing nødsaget til at tage sin afsked. I Af mit Levned ${ }^{9}$ ) findes denne skildring af den nødtvungne embedsafgivelse:

Jeg søgte altsaa min Afsked fra Universitetet. Men medens jeg overgav Filologien til Dr. J. L. Heiberg, ønskede jeg indtil videre at beholde Archæologien, og jeg skrev i min Ansøgning, at jeg gjerne vilde vedblive som Privat-Docent at holde Forelæsninger og Øvelser i dette Fag, indtil der kunde blive oprettet en særskilt Lærestol for det.

Jeg havde ligeledes haabet, at jeg kunde vedblive at være Regens- 


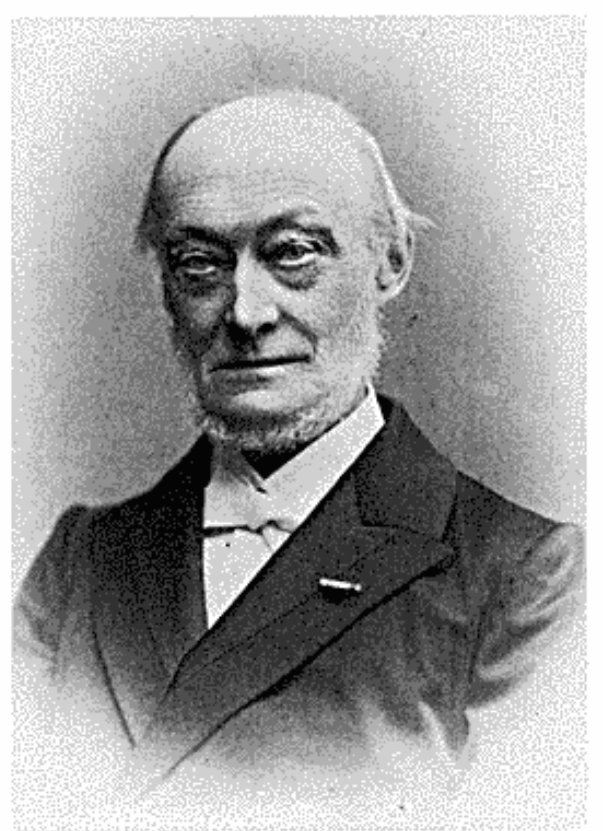

J. L. Ussing fotograferet februar 1896 . Det $\mathrm{kgl}$. Biblioteks Billedsamling.

provst, uagtet jeg opgav mit Embede som Universitetsprofessor. Jeg bildte mig ind, at jeg var paa min Plads der, og det syntes rimeligt, at jeg endnu i nogle Aar kunde have de fornødne Kræfter til at varetage de dermed forbundne Forretninger. Men man fandt det tvivlsomt, om dette lod sig forene med de gjældende Lovbestemmelser, og det juridiske Fakultet erklærede, at Regensprovsten derefter skulde være en virkelig Professor, ikke en emeritus. Ansete Jurister udenfor Universitetet havde en modsat Opfattelse og opfordrede mig til at henstille Spørgsmaalet til Ministeriets Afgjørelse; men dette afviste jeg bestemt; jeg vilde ikke udsætte mig for, at der blev gjort den mindste Rift i det venskabelige Forhold til mine Kolleger, som havde været mit Livs Lykke. Jeg søgte altsaa min Afsked som Professor fra 31. December 1895 , og jeg fratraadte Regensprovstiet ved Halvaarets Slutning 3I. Marts $\mathbf{I} 896 .{ }^{10}$ )

Ligeledes findes der i Ussings selvbiografi denne karakteristik af den unge Holger Pedersen, som han forekom ham i de år, Ussing var regensprovst og efor for Elers' Kollegium:

Ængstelig og forlegen var han, og han gik som en Eneboer mellem sine Kammerater; men paa Skolen fik han aldrig nogen anden Charakter end ug. Ogsaa Afgangsexamen bestod han med lutter ug; og det var 
godt, thi havde han ikke havt dette Stempel paa sig, vilde Ingen have opdaget ham i det Musehul, hvori han af lutter Forlegenhed gjemte sig. Jeg lærte ham at kjende paa mine Forelæsninger og var glad ved at faa ham ind paa Elers Kollegium og ved at faa ham til at komme i mit Hus. Han tog Skoleembedsexamen med Egregie, men til Skolemand var han ikke skabt. Han var kaldet til Videnskabsmand. Han stillede sig fra først af den Opgave, som han stadig fastholdt, at undersøge Sprogenes Historie og Sammenhæng. $\left.{ }^{11}\right)$

At Holger Pedersens udenlandsrejse kom til at vare hele 4 år skyldtes ifølge Ussing, at han „ved sjælden Sparsommelighed og Nøisomhed fik Stipendierne til at holde ud i 4 Aar." Udtalelsen om Holger Pedersens mange rene ug har han dog selv dementeret for et enkelt fags vedkommende, nemlig geografi, hvor hans lærer med ,god grund kun var mellem tilfreds" med ham ${ }^{12}$ ).

Professor Ussing slutter skildringen af Holger Pedersen, der i april 1900 var blevet ansat som extraordinær docent i sammenlignende sprogvidenskab, med en kommentar til det tilbud, Holger Pedersen fik om en stilling fra Basel Universitet i 1903: „En ærefuld Kaldelse til Universitetet i Basel har han afslaaet. Han siger som Rask: „Sit Fædreland skylder man Alt, hvad man kan udrette“."

Holger Pedersen kommenterer selv sagen på følgende måde: „.. . efter at jeg i 1903 havde fảet tilbud om ansættelse i Basel, blev der i 1903 for mig oprettet et ekstraordinært professorat i slavisk filologi og sammenlignende sprogvidenskab, som jeg i 1914 ombyttede med det ordinære professorat, som Vilh. Thomsen havde været indehaver av. Dermed havde jeg nået mine ønskers mål..."13)

Gennem hele sit lange forskerliv - han døde i 1953 - fortsatte Holger Pedersen sine sprogstudier og gav sit bidrag på en lang række områder inden for sprogvidenskaben med studier foruden af keltisk og albansk også f.ex. af hittitisk, lykisk, tokharisk, ikke at forglemme hans interesse for armensk. Om disse omfangsrige studier vidner bibliografien over hans trykte arbejder ${ }^{14}$ ) og hans efterladte papirer i Det kgl. Bibliotek.

Trods det til tider noget kritiske og mistrøstige syn på irerne og specielt Aran-boerne, som Holger Pedersen i sine breve lægger for dagen, skaffede irerne sig dog tilsyneladende en ret stor plads i hans hjerte ved deres hjælpsomhed. I alle tre versioner af sin selvbiografi nævner han irerne med taknemlighed for den hjælp, de engang ydede ham: „Nu til slut en tak udadtil. Først til mine venner irerne. Da jeg i I899 (den eneste gang $\mathrm{i}$ mit liv) befandt mig $\mathrm{i}$ en håbløs økonomisk 
situation, var det irerne i Amerika og specielt professor Henebry ${ }^{15}$ ) i Washington, der hjalp mig over de fortvivlede dage, ..." ${ }^{\text {"16) }}$

Højdepunktet i Holger Pedersens keltiske studier er hans Vergleichende Grammatik der keltischen Sprachen, I-II. Göttingen 1909-I3. Dette monumentale værk blev genoptrykt i 1976. I 1937 udkom en engelsk revideret og forkortet udgave foretaget i samarbejde med professor Henry Lewis (1889-1968). Også denne udgave er blevet optrykt senere, sidst i i 974 . Arbejdet med den forkortede udgave kan man følge i en række breve fra Henry Lewis til Holger Pedersen i den tid, arbejdet stod paa midt i $30^{\prime}$ erne. ${ }^{17}$ )

Om Holger Pedersens store grammatik skriver professor Kenneth $\mathrm{H}$. Jackson i 1976 :

I cannot omit mention of one of the most important, perhaps the most important, of works ever published on Celtic studies, Holger Pedersen's great Vergleichende Grammatik der keltischen Sprachen. This was an extraordinary feat of learning on the part of one single man, covering as it does the Indo-European origins and all the early, together with part of the later, history of the Celtic languages. [...] the VGK is still an essential tool of Celtic scholars, dated though part of it may be. ${ }^{18}$ )

De følgende breve fra Irland udgør et sluttet hele og virker som en kombineret rejsedagbog og forskningsrapport. De illustrerer på nært hold sprogforskeren Holger Pedersens indsamlingsarbejde. Sproglige og folkloristiske kommentarer er udeladt. Disse vil fremkomme i cand. phil. Ole Munch-Pedersens udgave af notesbøgerne og andre sproglige og folkloristiske optegnelser fra Aranopholdet. Brevene er gengivet i Holger Pedersens egen ortografi, bl.a. er hans brug af varianterne $\varnothing$ og ö tilligemed hans vekslen mellem $\mathrm{E}$ og $£ \mathrm{i}$ ordet eventyr søgt gennemført.

\section{Hr. Professor Ussing!}

Jeg skrev i mit sidste Brev, at jeg vilde skrive igen, såsnart jeg kom til Dublin, og dog har jeg nu været her næsten en hel Uge uden at skrive. Jeg har ventet indtil nu for bedre at kunne beregne, hvormange Penge jeg har brug for i den nærmeste Fremtid. - Jeg tog fra Greifswald Onsdag d. 7. Avgust om Morgenen Kl. 6, nåede til Hamburg Kl. 6 om Eftermiddagen og tog samme Aften med en Damper til Grimsby. Overfarten varede næsten halvandet Døgn, så at jeg var i Grimsby Fredag d. 9. Avgust om Morgenen Kl. 6. Jeg tog straks med Toget til Liverpool, hvor jeg måtte vente indtil Aften; Kl. 7 afgik en Damper, og 
den ankom til Dublin Lördag Morgen Kl. 5. Jeg tog ind på et Hotel, men gik allerede tidlig om Morgenen ud for at søge et Værelse, men det tegnede ikke til, at jeg skulde have Held med mig. Jeg henvendte mig derfor til et Bolig-Bureau (W. Purcell, I Suffolk Street), hvor man anviste mig en meget tilfredsstillende Bolig i Byens sydligste Udkant; jeg har her et bedroom og et sittingroom tilligemed fuld Kost for I $_{5}$ Shilling i Ugen. I Bureauet betalte jeg I Shilling. Inden jeg fik dette bragt i Orden, var det meste af Dagen gået, og da det tilmed gav sig til at regne, blev jeg hjemme Resten af Dagen (for Resten har det regnet hver Dag siden da med Undtagelse af igår). Om Söndagen kunde jeg heller ikke foretage mig noget, men benyttede Tiden til at overvære Gudstjenesten i en katholsk, en engelsk („Irish church“) og en methodistisk Kirke. Om Mandagen begav jeg mig straks til Royal Irish Academy. Jeg ved ikke, om Professoren kender Dublin; i modsat Fald venter De rimeligvis, at jeg nærmere skal definere, hvad Royal Irish Academy er, men jeg må opsætte denne Definition til næste Gang; jeg har nemlig undladt at købe en Bædeker og troet, at jeg vilde være bedre hjulpen med en engelsk "Guide to Dublin", men denne „Guide" lader mig ynkelig i Stikken - ja, jeg er bleven så vred på denne Bog, at jeg ikke kan nægte mig selv at citere et Par Ting af den; under Kapitlet „The Statues in Dublin" læses: "Nelson's Pillar ${ }^{19}$ ) is not only the tallest in the city, but it serves a very useful purpose as the starting-point of many of the tramcars"; i et indledende Kapitel om Byens Historie hedder det: "Its annals, as a town, extend back to a period anterior to the dawn of history, and are, of course, mixed up with much that is - well, of doubtful accuracy“. Denne „vittige“ Vending er al den Kritik, som udøves, og derefter meddeles blandt andre mærkelige Ting, at de Danske landede i Dublin i Året $43^{8}(\mathrm{sic}) .^{20}$ ) Denne interessante „Guide to Dublin " meddeler naturligvis heller intet om Royal Irish Academy, ${ }^{21}$ ) der, efter hvad jeg antager, er et „Videnskabernes Selskab“; det har en egen Bygning og et Bibliothek. Ved dette Bibliothek er der ansat en Mand ved Navn Mac Sweeney, der tillige er ,Secretary to the Society for the Preservation of the Irish Language ${ }^{\text {"22 }}$ ). Til ham havde jeg en Anbefaling fra Professor Zimmer, og straks om Mandagen henvendte jeg mig til ham. Efter hans Råd købte jeg nogle Småbøger udgivne af dette Society; jeg har allerede omtrent læst dem igennem og skal nu have nogle Timers Udtaleøvelser hos en nyirsk Lærer, som Mac Sweeney har anvist mig. For Resten er det mere for at lære Engelsk end for at lære Irsk, at jeg har bestemt at blive i Dublin indtil Slutningen af Avgust. Jeg anser det for vigtigt her at købe Facsimile af de to vigtigste 


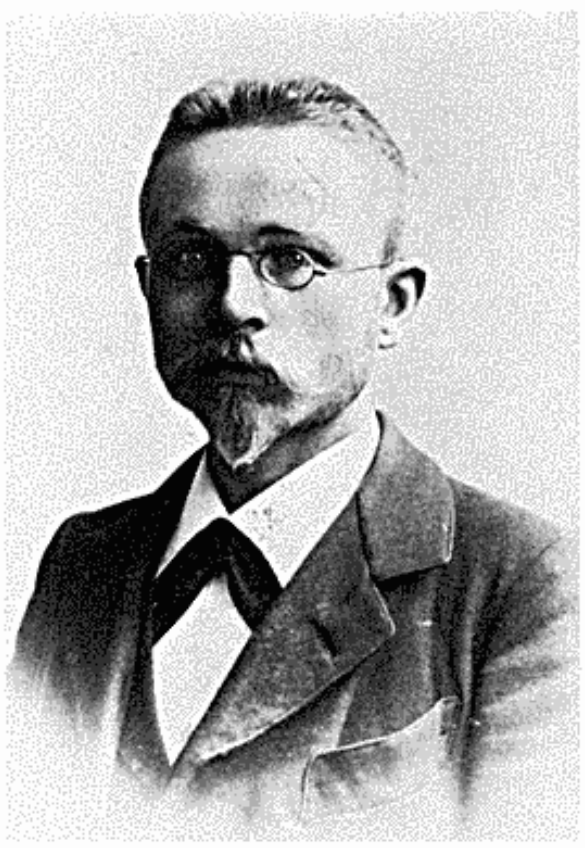

Holger Pedersen fotograferet i Greifswald 1895 eller 1896. Originalen tilhører Holger Pedersens niece Gudrun Krogsgaard.

mellemirske Sagahåndskrifter, ${ }^{23}$ ) da jeg her ad forskellige Omveje kan opnå en Rabat på omtrent 30 Shilling. Derefter vil de to Håndskrifter komme til at koste mig $£ 7^{1 / 2}$. - Det er vanskeligt for mig at vide nöjagtigt, hvorledes jeg bedst skal indrette mine Pengesager; navnlig er jeg uvidende om, hvor let eller vanskeligt man kan få Penge tilsendt i det vestlige Irland. Efter den bedste Beregning, jeg kan anstille, beder jeg Dem om at sende mig en Sum omtrent som 300 Shilling. Så har jeg ialfald nok foreløbig. Hvis det er om Lördagen, Professoren plejer at komme ind til Byen, er det selvfølgelig tidligt nok at afsende Pengene Lördagen d. 23. Avgust, da jeg ikke rejser herfra förend en af de sidste Dage i Måneden. Min Hilsen til Dem og Deres Familie. ${ }^{24}$ )

\section{Hr. Professor Ussing!}

Jeg takker Dem for Deres Brev og for de tilsendte $£_{15}$ (= 300 Shilling), som jeg idag har modtaget. Med Udbetalingen af Penge går det således til: Postanvisningen hjemmefra ser jeg ikke noget til, men derimod bliver der mig tilsendt en money order, udstedt i London, jeg afhenter så selv Pengene i Posthuset, hvor jeg må svare på Spörgsmålet: Who sent the money order? Men Postvæsenet i London havde denne Gang skrevet 
min Adresse forkert, „Mount Pleasant Road“ istedenfor „Mount Pleasant Parade", hvilket muligvis har forvoldt nogen Forsinkelse, idet Postbudet havde spurgt efter mig i Mount Pleasant Square, Mount Pleasant Avenue, Old Mount Pleasant o.s.v., för end han fandt på at komme til Mount Pleasant Parade. Da det danske Postvæsen altså åbenbart kun har at gøre med London, formoder jeg, at Postanvisninger kan sendes til alle Egne af de tre Kongeriger. - Jeg har her i Dublin forberedt mig til min Vestfærd ved at læse en Del irske Æventyr fra Connaught: ${ }^{25}$ ) nogle af dem er i fonetisk Gengivelse, men de fleste af dem i historisk Orthografi; disse sidste gennemgår jeg under Vejledning af en Mand fra Connaught, Farrelly, der vel omtrent har den noget ejendommelige engelske Skolelærer-Uddannelse (der består af Stumper af alle Fag, der hører til den akademiske Uddannelse, også Latin og Græsk; en Uddannelse, der er vel skikket til at give disse Folk den Illusion, at de kan alt muligt, medens de i Virkeligheden savner de Kundskaber, som er mest nødvendige for Almueskolen); han synes at være meget betroet her i Dublin til Udførelsen af forskellige Slags videnskabeligt Håndlangerarbejde. Jeg er meget vel tilfreds med ham som Lærer i Nyirsk. Overbevist om sin egen Indsigt kan han ikke dy sig for også af og til at meddele mig Oplysning om Ordenes Etymologi; disse Oplysninger sluger jeg uden at fortrække en Mine og uden at modsige ham.

Sidste Tirsdag var jeg tilstede ved et council meeting of the Society for the preservation of the Irish language. Her måtte jeg deltage i en latterlig Diskussion om det irske Sprogs Oprindelse, som indlededes af Mir Anlad Ali, en Inder, der er Professor i orientalske Sprog her, og som fremsatte den Anskuelse, at Irsk var nær beslægtet med Arabisk. Da de øvrige tilstedeværende åbenbart stod Sprogvidenskaben omtrent ligeså fjærnt som Mir Anlad Ali, kunde jeg nær være kommen i en slem Forlegenhed, da det som bekendt ikke er til nogen Nytte at kaste Perler for Svin; men til alt Held viste det sig, at Selskabets Præsident, en gammel Gejstlig ved Navn Close ${ }^{26}$ ) (Medlem af Royal Irish Academy), vidste særdeles god Besked om Sagen; så jeg behøvede blot at slutte mig til ham og illustrere hans Udtalelser med forskellige Eksempler, som jeg hentede fra Nyirsk og Nygræsk (nyirsk amarach [a udtalt som vort å, ch som tysk ch] betyder "tomorrow" og er dog aldeles ikke beslægtet med det engelske Ord, som man kan se, så snart man kaster et Blik på

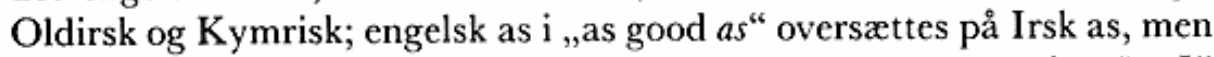

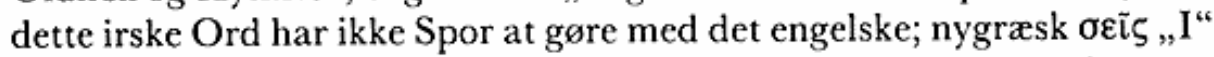
stemmer aldeles tilfældigt overens med tyrkisk siz "I" - dette er 


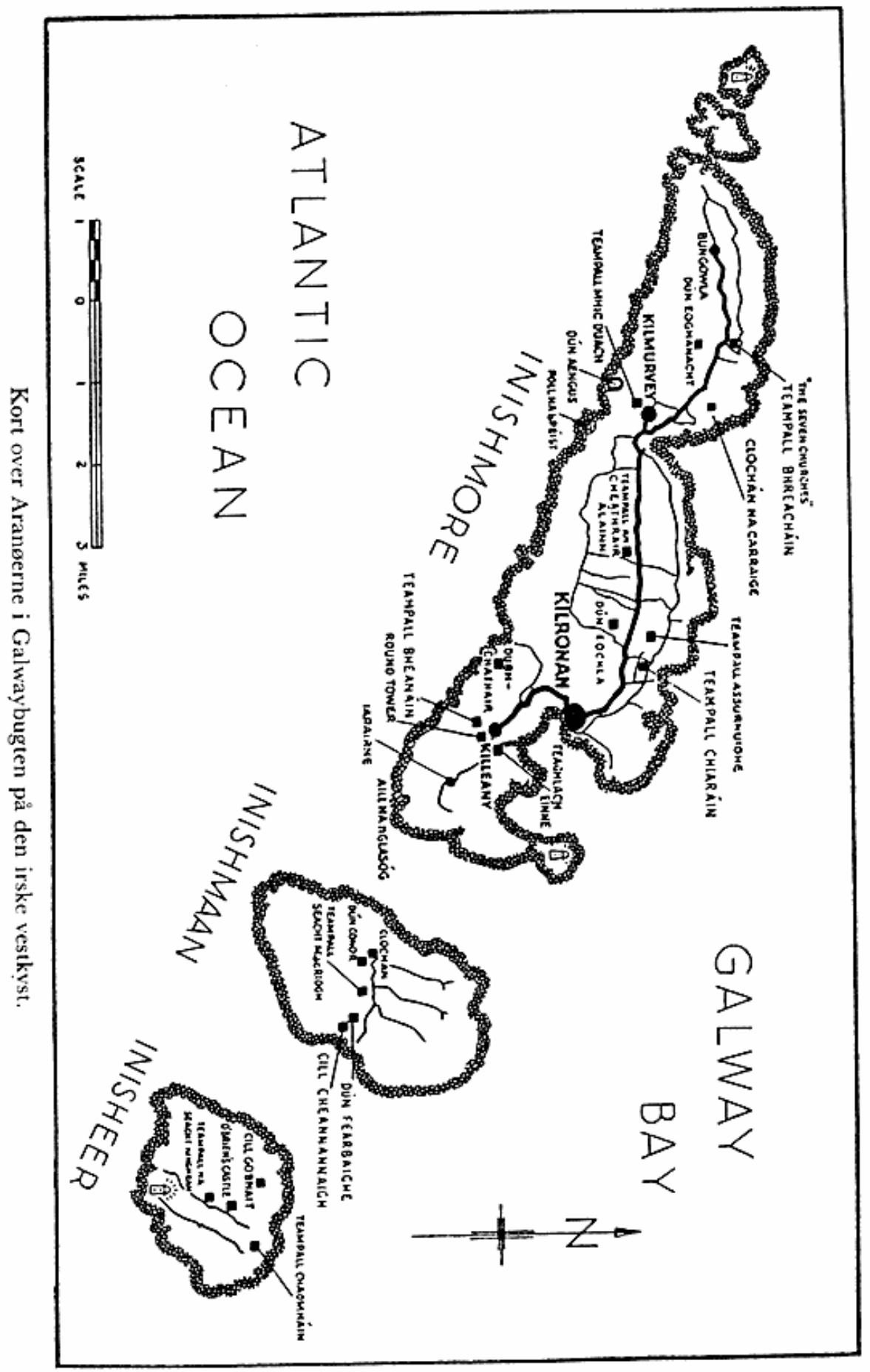


Eksempler på, hvor hyppige tilfældige Ligheder mellem forskellige Sprog er, og hvor nødvendig en systematisk Sammenligning er, för man taler om Slægtskab). Dette fandt de tilstedeværende var en interessant Diskussion. Jeg meldte mig ind i Selskabet, hvilket jeg vidste, at man ønskede, og to Dage efter kunde man læse i Avisen en udførlig Beretning om Mødet (med Professor Zimmers og mit Navn). Hermed er det ikke forbi, men man er bestemt på at udvælge mig til Bestyrelsesmedlem. Som De ser, er Foreningen ikke betænkt på at undgå det komiske Skær, som den Slags Bestyrelsesmedlemmer må kaste over den.

I Söndags var jeg tilligemed Rev. Close indbudt til Lunch hos Prof. Atkinson, der er Professor i sammenlignende Sprogvidenskab her og en Mand med et anset $\mathrm{Navn}^{27}$ ). - Close har foræret mig det ene af de Facsimiler, jeg vilde købe; dets Bogladepris er i 26 Shilling. Således befinder mine Pengeforhold sig i en meget gunstigere Forfatning end jeg havde beregnet, endskönt jeg har købt Bøger for over 80 Shilling og givet 30 Shilling ud til Undervisning.

- På Fredag afrejser jeg til Arran-øerne.

- Mine arbødige Hilsener til Dem og Deres Familie. ${ }^{28}$ )

Aranøerne var i slutningen af det $\mathrm{I} 9$. århundrede stedet, hvortil folk, der var interesserede i keltisk sprog og folklore, nærmest valfartede. Ikke blot sprogforskere som Holger Pedersen og F. N. Finck (1867-1910) og folklorister som amerikaneren Jeremiah Curtin (I840-1 1906), men også digtere som W. B. Yeats (1865-1939) og J. M. Synge (1870-1909). Yeats besøgte øerne $\mathrm{i}$ sommeren 1896 , altså lige efter Holger Pedersen. ${ }^{29}$ ) Synge rejste til Aran på opfordring af Yeats, forste gang i forsommeren I 898 . Han aflagde ialt 5 besøg på Aran mellem i 898 og 1902. Indtryk og oplevelser fra disse ophold skildrede han i bogen The Aran Islands $(\text { I } 906)^{30}$ ). Denne virker som et supplement til Holger Pedersens breve, ikke mindst fordi den person, som Holger Pedersen skildrer sit nære samarbejde med ved indsamlingen af sit sproglige og folkloristiske materiale, også optræder i Synge's bog. Vi får i de to skildringer et levende billede af en gammel Aranboer, nemlig Holger Pedersens Martin Conneely og Synge's Mourteen.

Hr. Professor Ussing!

I Fredags (d. 30. Avgust) forlod jeg Dublin tidlig om Morgenen med det forste Tog og ankom til Galway Kl. I I 1/2; næste Dag Kl. ro $1 \frac{1}{2}$ skulde der gå en Damper til Aran. Tog- og Dampskibsplaner er således indrettede, at man ikke kan rejse fra Dublin til Aran uden at overnatte i Galway. 
Galway er en lille By; Hotelværten sagde, at den har 16.000 Indbyggere, hvilket jeg ikke finder nogen Grund til at tvivle om (min engelske „Bädeker" røber selvfølgelig ikke den slags Hemmeligheder). Byen ligger malerisk ved Udløbet af Floden Gallive; tidligere skal den (ifølge min pålidelige engelske Rejsebog) have drevet betydelig Handel på Spanien; nu er det første og sidste Indtryk, man får af Byen, Fattigdom; lasede Börn, barfodede Kvinder, forfaldne Huse ser man overalt. Det ejendommeligste Kvarter er måske det såkaldte Claddagh, der består af lutter bittesmå stråtækte Huse byggede i temmelig uregelmæssige Rækker, som man næppe altfor let kan inddele i Gader. Dörene består af en øvre og en nedre Halvdel ligesom Ladedöre; Vinduerne er små og så lave, at Hönsene med Lethed springer op i Karmen. I dette og i andre Kvarterer af Byen ser man Masser af Huse i Ruiner; jeg så hele lange Rækker af sådanne Ruiner. Sagen er vel den, at de er opførte på en så primitiv Måde og af så værdiløst Materiale, at det ikke er Umagen værd at brække dem ned. Jeg hørte næsten ikke andet end Engelsk på Gaden; små Börn og gamle Kvinder talte Engelsk; en eneste Gang hørte jeg Irsk. Om Lördagen ankom jeg her til disse aldeles skov- og træløse Klippeøer. Aran gør et bedre Indtryk end Galway. Irlænderne ser godt ud i deres hvide uldne Dragt med den brede Hue på Hovedet, og man har ikke her det Indtryk af yderlig Fattigdom som i Galway. Hver Landsbys Huse ligger tæt sammen (anderledes end i jyske Landsbyer); Husene er små, opførte af Kampesten (dem har man nok af her); i Gaderne græsser der Flokke af Svin, ${ }^{31}$ ) også Ænder og andre Fugle. Utallige Stengærder inddeler Jorden i en Masse små Indelukker uden nogen Indgang; når man vil ind, går man over Stendiget; skal Korn eller Kreaturer bringes ud derfra, river man et Stykke af Hegnet ned og stabler det bagefter op igen. Hegnene tjener til Læ for Kreaturerne, som bliver ude hele Vinteren (så mildt er Klimaet her). Store Strækninger af Øen består af nøgen Klippegrund; nogle Steder danner Kysten en höj brat Klippevæg; går man ovenpå Klippemassen, finder man nogle Steder dybe Huller, gennem hvilke man kan se Havet; i Storm kastes der (jeg har endnu ikke set det) store Vandmasser op gennem disse Huller, som derfor hedder puffing caverns. - Først idag henvendte jeg mig til Præsten Father Colgan, der viste sig meget villig til at hjælpe mig tilrette på enhver 'Måde; jeg tænker, at jeg vil kunne vinde rigt sprogligt Udbytte her. Præsten tilligemed hans Curate gik med mig til en Skole i en anden Landsby et godt Stykke Vej herfra. En Lærer og 2 Lærerinder underviste her i et og samme Lokale; det var en Fællesskole for Drenge og Piger. Vi hørte på Undervisningen i Irsk. Undervisningssproget er 
Engelsk. En Mængde Mennesker her på Øen kan tale Engelsk; Præsten talte Engelsk med de fleste, vi mødte, med nogle talte han Irsk. Man kan høre Börn tale Engelsk med hinanden. Den nu opvoksende Generation vil åbenbart være den sidste, der taler eller kan tale Irsk; så vil det gamle Sprog forsvinde også fra disse fjærne $\varnothing e{ }^{32}{ }^{32}$ ) Den nordlige $\varnothing$ (hvor jeg bor) og den sydlige $\varnothing$ er allerede omtrent bilingve; den midterste $\varnothing$ er endnu rent irsk, men også dèr er Undervisningssproget Engelsk.

Når jeg har fået begyndt på mit sproglige Foretagende, skal jeg lade høre fra mig igen. Mine ærbødige Hilsener til Dem og Deres Familie.

Min Adresse har jeg skrevet ovenover Brevet; da Navnet Aran også bæres af andre Øer, er det nødvendigt at tilføje Angivelsen co. Galway. Aranmore („Stor-Aran“) er Angivelsen af, hvilken af de tre øer, der er ment. ${ }^{33}$ )

Holger Pedersen beskriver ikke hotellet, og Synge giver kun et skitseagtigt indtryk af det i sin bog: „I am in Aranmor, sitting over a turf fire, listening to a murmur of Gaelic that is rising from a little public-house under my room. "34) Men forfatteren Arthur Symons (1865-1945), der i I 896 besøgte Aran, giver en særdeles detailleret skildring af hotellet: $\ldots .$. a very primitive hotel $[\ldots]$ The kitchen, which is also the landlady's bedroom, presents a medley of pots and pans and pettycoats as you pass its open door and climb the little staircase, diverging oddly on either side after the first five or six steps, and leading on the right to a large dining room, where the table lounges on an inadequate number of legs and the chairs bow over when you lean back on them." Og han beskriver ligeledes ,... the little musty bedroom on the other side of the stairs, with its half-made bed, its bare and unswept floor, its tiny window, of which only the lower half could be opened, had to be supported by a wooden catch from outside." 35 )

Holger Pedersens første indtryk af Aran har et sidestykke i Synge's skildring af $\sin$ første spadseretur på øen: „... I was wandering out along the one good roadway of the islands, looking over low walls on either side into small flat fields of naked rock. I have seen nothing so desolate. Grey floods of water sweeping everywhere upon the limestone, making at times a wild torrent of the road, which twined continually over low hills and cavities in the rock or passed between a few small

På modstående side: Parti med marker og stendiger på Inishmore, Aran Islands, jfr. Holger Pedersens breve af 2.9. og 6.10.1 895 s. $9^{2} \mathrm{og}$ s. $9^{6}$. Det kgl. Biblioteks Billedsamling. 


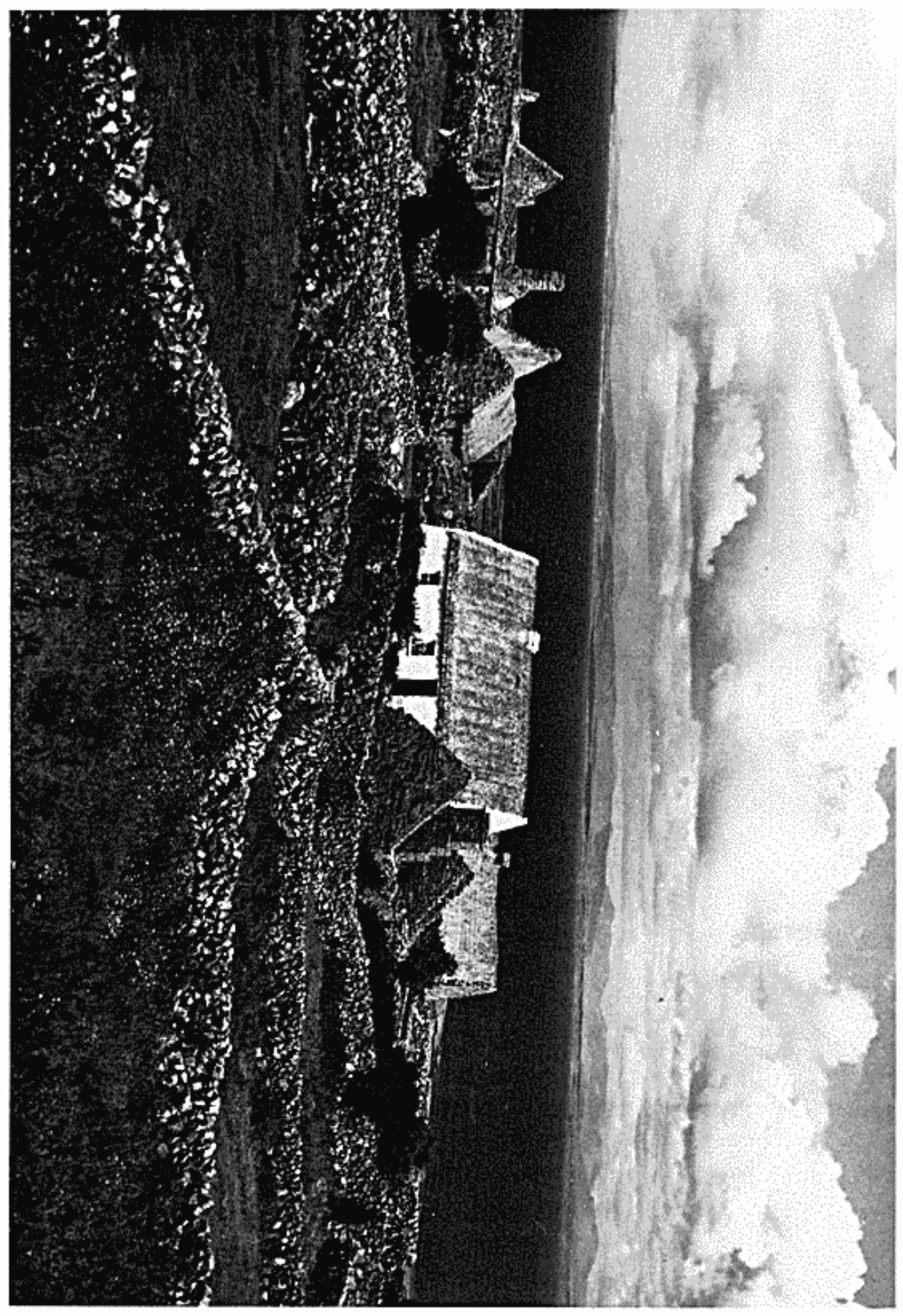


fields of potatoes or grass hidden away in corners that had shelter." ${ }^{\text {" }}$ )

Der kom til at gå en måned før Holger Pedersens ,sproglige Foretagende" kom så godt igang, at han havde noget positivt at berette. Det har tydeligvis været alt andet end let for ham at komme på bølgelængde med irerne. Men han klarede dog skærene, og i begyndelsen af oktober sender han en længere beretning til Ussing:

Hr. Professor Ussing!

Jeg har jo nu været 5 Uger på Aran, og det er vel derfor på Tide, at jeg lader høre fra mig. Jeg vil først sige et Par Ord om Øen og derefter fortælle om mine irske Studier. Jeg fortalte vel allerede sidste Gang, at Øen udelukkende består af Klipper, som danner höje lodrette Vægge ud imod det atlantiske Hav - dog er Udtrykket, „lodret“ ikke ganske korrekt, da Havet de fleste Steder har slidt det nederste af Klippen bort, så at den nu hænger ud over Vandet. Havet larmer altid mod disse Klipper, selv når Vejret er stille, og idet det skyller ind under dem, frembringer det en hul Torden. Når det er Storm, slår de hvide Skumbølger helt op over Klippens øverste Rand. Til den anden Side, ud mod Galway Bay skråner Terrænet jævnt eller trinvis nedad. Øens höjeste Ryg er kun ubetydeligt höjere end den yderste Rand langs Atlanterhavet. Øen får et ejendommeligt Udseende ved den Mængde Stenhegn, der inddeler Øen i et uhyre Antal små bitte Indelukker. Åbenbart er dette tildels ikke andet end et Middel til at befri Markerne fra Stenene; muligvis har Hegnene også den Bestemmelse at yde Kreaturerne Læ om Vinteren. Disse Hegn gör det temmelig vanskeligt at komme frem uden for de egentlige Veje, idet man hvert tredie Sekund må klavre over et Hegn, hvis øverste Sten ligger så løst, at man hverken med Hænder eller Fødder kan røre ved dem uden Fare for, at de skal falde ned. ${ }^{37}$ ) Der findes en Del Mindesmærker fra ældre Tid her på Øen; det mest iöjnefaldende er 4 gamle Fæstninger, „Dún“. En af dem, som med et kunstigt opfrisket Navn hedder Dún Oengus, ligger på Randen af en höj Klippe ud mod Atlanterhavet og består af en halvkredsformet Mur, der er åben ud mod Atlanterhavet. Muren, der er opført af Sten uden Kalk eller andet Bindemiddel, har en forsvarlig Tykkelse; jeg kan kun angive et meget unöjagtigt Mål: jeg målte med min Paraply og fandt, at Murens Tykkelse var 4 Gange Paraplyens Længde, altså 5 Alen eller mere. Denne Tykkelse har Muren dog kun fra Jorden til omtrent $\mathrm{i}$

På modstående side: Dun Oengus, Aran Islands, jfr. Holger Pedersens brev af 6.10.1895, som indledes på denne side. Det kgl. Biblioteks Billedsamling. 


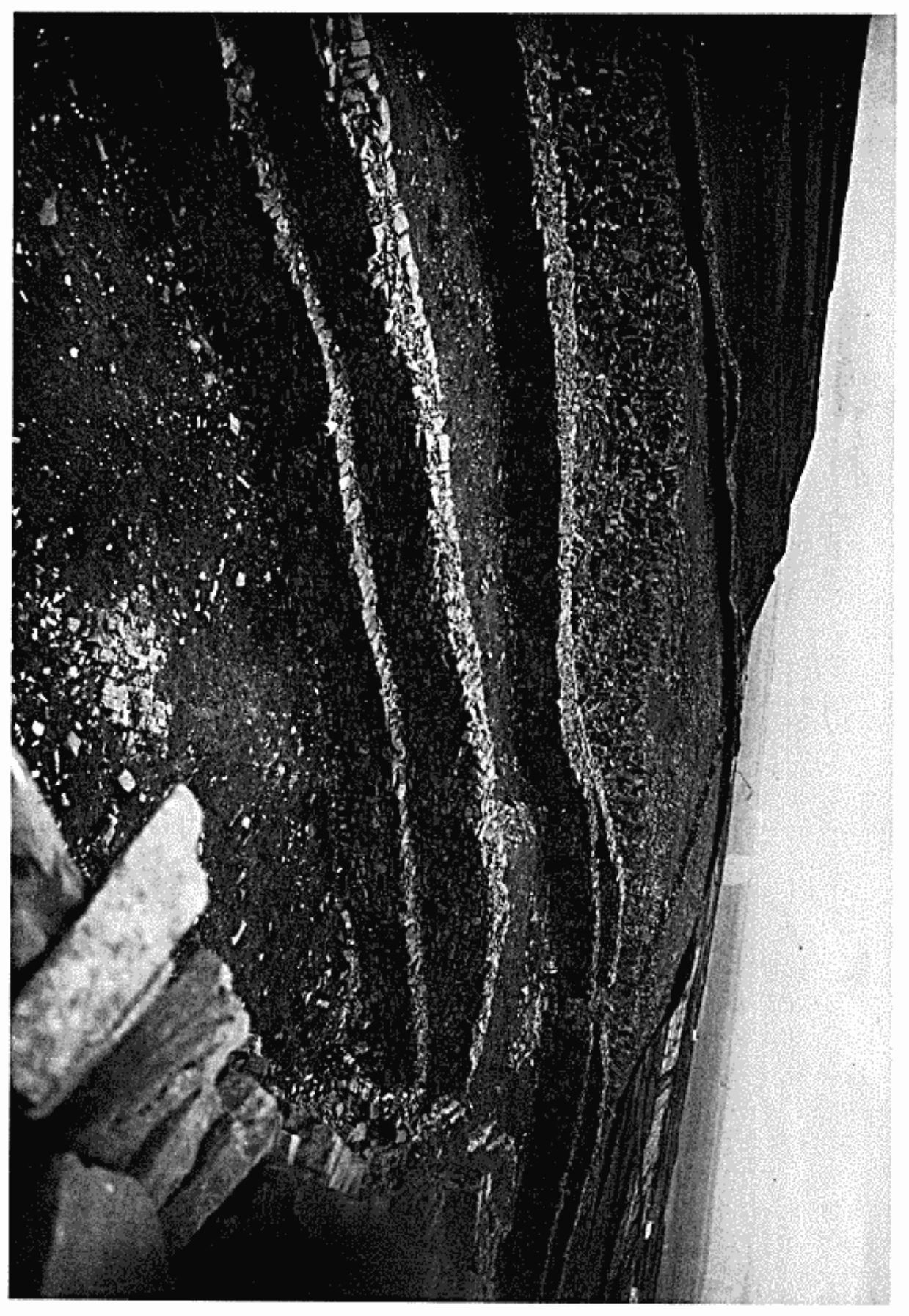



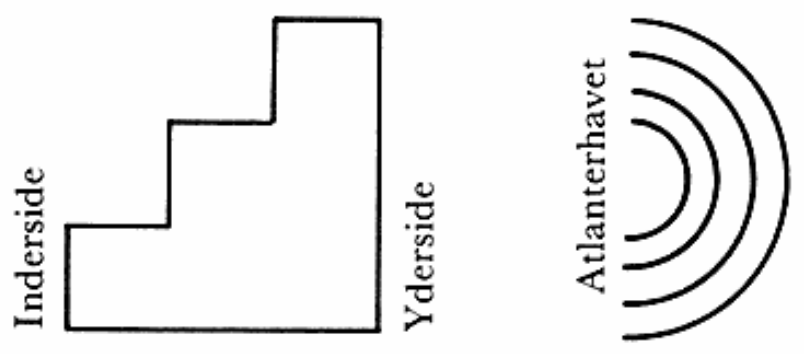

Mandshöjde; den hosstående „Tegning“ viser, hvorledes et Gennemsnit af Muren ser ud; en af mine Aran-Bekendte, den gamle Sømand Marc $O$ Flaherty gör den muligvis brugbare Bemærkning, at Muren ved at bygges på denne Måde kunde opføres uden Hjælp af Stillads. Murens andet Afsnit har ikke fuldt Mandshöjde, og det tredie er endnu lavere. Uden om denne Mur findes der endnu tre andre forsvarlige Mure i större og större (ikke nöjagtigt concentriske) Halvkredse. Den yderste af disse Mure indeslutter et meget stort Areal. Indgangen gennem den inderste Mur består af en lav Port, som man ikke kan gå oprejst igennem. Da jeg havde taget Fæstningen i Öjesyn og vilde til at gå, opdagede jeg, at der stod en Fisker derinde. Jeg gav mig i Samtale med ham, og han fortalte mig, at dette Dún havde tilhørt et Slags Mennesker, som kaldtes Lochrannach. Dette Sagn er blottet for al historisk Grund; Lochrannach, eller, som Ordets aldre Form lyder, Lochlannach, betyder nemlig ikke andet end „Dansk"; Lochlann er Danmark. Om dette Navn, som Professor Zimmer mener, er identisk med „Låland" og således et Vidnesbyrd om, at de første Vikinger kom fra denne $\varnothing$, skal jeg være usagt. Da loch betyder „Sø“ og lann er et godt irsk Ord (med Betydningen "Land"), kunde man også fantasere om, at Navnet var en Irisering af "Sæland“ (skönt denne $\varnothing_{\mathrm{s}}$ Navn oprindelig ikke indeholder ordet „Land“). Og den Omstændighed, at mere end én Forklaring er mulig, må bringe forsigtige Mennesker til at ignorere begge Forklaringer, men skal man vælge en af dem, er Zimmers Tydning utvivlsomt den sandsynligste, især hvis han har Ret $\mathrm{i}$ at Skrivemåden Lothlann er ældre end Lochlann (th udtales nu som $\mathrm{h}$, ch som tysk ch). Danske Vikinger nåede virkelig i ro81 til Aran, men videre end de selv nåede Rygtet om dem, så at en senere Tids FolkeFantasi satte alt, hvad der var stort og vældigt i Forbindelse med disse Lochlannach, deriblandt også Ting, som de er absolut uskyldige i, f.eks. dette Dún. Den omtalte Fisker havde åbenbart ingen Anelse om, hvad disse „Lochrannach“ egentlig var, kun at de var nogle vældige Karle; 
han vilde sikkert have gjort store Öjne, om jeg havde sagt til ham: ,Jeg er selv en Lochrannach" - og derfor sagde jeg det ikke. Andre af Øens Beboere véd dog godt, at Lochlann er Danmark; en af dem fortalte mig, at de Danske i sin Tid havde boet på Aran; dette er også galt, der var intet, der kunde friste Vikinger til at bosætte sig på denne $\varnothing$. En Dag, da jeg med Marc O Flaherty gik gennem Landsbyen Killeany, spurgte en Kone om, hvor jeg var fra; Marc svarede, at jeg var fra Lochlann, så han har åbenbart både selv kendt Navnet og også anset det for forståeligt; dog forekom det mig, at denne Oplysning imponerede den brave Kone i höj Grad. Jeg skulde imidlertid ikke tale om Ordet Lochlann, men om de gamle Dún. Foruden Dún Oengus ligger endnu et andet Dún ved Atlanterhavet (Dún Dubh Chathir eller som Marc angiver Dún Dà Chathir, „den sorte Stads Dún“ eller (iflg. Marc) „de to Stæders Dún“). To andre ligger inde i Landet, og Muren danner derfor ikke en Halvkreds, men en hel Cirkel. Men der har været endnu flere Dún, som tildels endnu kan spores. Hvad alle disse Fæstninger skulde på denne lille Ø (knap 2 danske Mil lang og $1 / 3$ dansk Mil bred, hvor den er bredest), véd jeg ikke. Der er nutildags ${ }_{5} 5$ Landsbyer på denne $\varnothing$, og de er så små, at de tilsammen kun har 1800 Indbyggere. ${ }^{38}$ ) De omtalte Dún kunde næppe udholde en lang Belejring, da de mangler Drikkevand. - Der findes også Levninger af gamle Huse; et af dem er så godt som fuldstændig bevaret, det er udelukkende af Sten. Murene går lige op til en vis Höjde og derefter nærmer de sig til hinanden, idet hver Sten er lagt et lille Stykke ud over den nærmeste Sten nedenfor; efter at Murene på denne Måde er bragt temmelig nær til hinanden, er nogle store flade Sten lagt fra Mur til Mur som Tag. Et sådant Hus kaldes clochán.

- Endvidere findes der en Mængde Ruiner af Kirker, alle meget små. Nar ved Landsbyen Onacht er der et helt Kompleks af sådanne Kirker, hvorefter Landsbyen også fører Navnet „de 7 Kirker." Ved Landsbyen Killeany ligger der en Kirke helt oppe på Øens höjeste Ryg, ${ }^{39}$ ) en anden Kirke 0: Ruin ligger helt nede ved Kysten og er omtrent begravet $\mathrm{i}$ Flyvesand..$^{40}$ ) Omkring denne Kirke er en af Øens Kirkegårde: uden Indhegning, uden Træer, uden Blomster, de flade liggende Gravstene tildels begravede i Sand; den kolde Vind fra Havet stryger uhindret hen over denne Kirkegård. Nu er der kun én Kirke, men den er rigtignok en hel Del större end disse Ruiner. Desuden er der en protestantisk Kirke, men så godt som ingen protestantisk Menighed.

Da jeg ankom til Aran og søgte efter en Mand, som jeg kunde have Nytte af ved mine irske Studier, henviste man mig til den gamle Sømand Marc O Flaherty. Jeg opsøgte ham; han erklærede, at han „could not 
attend" den første Uge uden at forsømme sit Arbejde (han er Sejlmager). Dette anså jeg for Arrogance, da jeg naturligvis kun tænkte at lægge Beslag på ham en Time eller to hver Dag. Da jeg selvfølgelig ikke kunde gå ledig en hel Uge, fik jeg fat i en ung Mand Michel Flaherty og begyndte mine Sprogstudier ved daglig at eksaminere ham; han besad det store Fortrin ikke at kunne læse Irsk. En Samling irske Æventyr benyttede jeg som Grundbog, $\left.{ }^{41}\right)$ idet jeg Sætning for Sætning forelagde ham disse Æventyr på Engelsk og lod ham oversætte det på Irsk. Jeg nedskrev hans Oversættelse $\mathrm{i}$ fonetisk Skrivemåde og sammenlignede det med Originalen. Jeg må i et følgende Brev skrive noget mere om den irske Orthografi, der er meget interessant og i Grunden meget vel afpasset efter Udtalen, men meget langt fra at være fonetisk (saothruighthe udtales sīrì, breathnughadh udtales bŕanū o.s.v.) og ubrugelig til at gengive dialektiske Ejendommeligheder. I næste Uge dukkede så Marc O Flaherty op. Det viste sig, at han havde tænkt sig at „attend“ det halve af Dagen, for at få en hel Dagløn ud af det. Det viste sig fremdeles, at han ganske vist var en særdeles forstandig Mand, men at han idelig skolemestererede Dialekten; selvfølgelig kunde han læse. Jeg så snart, at jeg intet kunde stille op med denne indbilske og selvkloge, men uvidende Mand, hvis gode Forstand ikke kunde bøde på hans manglende Forståelse for mit Formål. ${ }^{42}$ ) Med en licentia poetica erklærede jeg ham derfor, at mit egentlige Formål ikke var at studere Sproget, men at samle Æventyr. Ledsaget af Marc begav jeg mig så til Øens avtoriserede Æventyrfortæller Martin Conneely, en $7 \mathrm{I}$-årig Mand, der ikke kan tale Engelsk. Han boede i et lille Hus uden Vinduer; Lyset kom ind ad den åbenstående Dör. Hele Huset bestod kun af et lille Rum; i et Hjörne lå to Svin og sov, ved siden af sad nogle Börn og legede; en Madgryde hang over Ilden, men da der ingen ordentlig Skorsten var, var Huset fuldt af Røg, som skar i Öjnene. Gulvet - af Ler eller Snavs? - bugtede sig i Bakke, Dal, så at den Bænk, der bødes mig at sidde på, ikke kunde stå fast. I den anden Ende af Huset var Senge (Afstanden fra den ene af Huset Sidevægge til den anden omtrent $=$ en Sengs Længde). Den mest iöjnefaldende Del af Møblementet var iøvrigt en stor Rok. I Almindelighed er Husene her lidt bedre end dette Hus, der betænkeligt minder om den ovenfor beskrevne clochán; men Svinene synes altid at have deres Plads i Dagligstuen. Næste Dag kom så Martin for at fortælle Eventyr. Det viste sig, at han ikke kunde diktere sine Eventyr, men kun fortælle dem i en ustandselig Fart under den livligste Gestikuleren. Desuden forlangte han en urimelig Betaling og erklærede, at han vilde ,skamme sig“ ved at tage imod den Betaling, jeg bød ham. 
Folk her tror, at enhver Udlænding er en uudtømmelig Guldkilde, og de vilde allesammen „skamme sig, “ hvis de ikke gjorde deres Bedste for at flå ham. De er så naive, som den Dreng, der, da jeg kørte i Toget (3. Kl.) i Grækenland, sagde til sin Fader - ikke anende, at jeg forstod Græsk, - at min Rejsetaske sikkert var proppet med Napoleondorer; ja, havde den bare været det, så kunde jeg have fortsat min Rejse i en halv Snes År uden at komme i Pengenød. Når Martin fortæller sine Eventyr, og Helten kommer i det Tilfælde at skulle spörge om Vej, giver han heller aldrig mindre end et Pund eller en "Savren“ (Sovereign) i Drikkepenge. Da jeg nu ikke kunde følge disse Æventyrheltes Eksempel, endte det med, at Martin fik sin Afsked på gråt Papir straks den første Dag. Jeg fortsatte så i en Ugestid mine Studier med Marc O Flaherty som Autoritet. Da dette var den rene Jammerlighed, besluttede jeg at rejse fra Aran og tage over til Galway. Ganske vist er i Byen Galway det herskende Sprog Engelsk, men det omliggende Land er irsk-talende, og der er sikkert en Mængde irsk-talende Personer i Byen selv. Og her på Aran er Irsk heller ikke eneherskende; man hører mere Engelsk end Irsk her i denne Landsby (Kilronan); de små Börn taler Engelsk indbyrdes, der er næppe en Mand på hele Øen, der ikke kan noget Engelsk; selv den gamle Martin, der, som jeg ovenfor sagde, ,ikke kan tale Engelsk,“ kan til syvende og sidst Engelsk nok til at kunne hjælpe sig frem dermed. Det irske Sprog er dødsdömt, og den Tid vil snart komme, da man forgæves vil søge efter det i den fjærneste Afkrog af Irland, om det vil holde sig i Amerika, véd jeg ikke. Som sagt, jeg besluttede at forlade Aran; men jeg kunde dog ikke bekvemme mig til at rejse herfra uden at have gjort endnu et Forsøg med Martin. Ledsaget af Marc begav jeg mig igen til hans Hus; vi traf ham nede ved Stranden beskæftiget med at bjærge Tang. Vi begyndte at parlamentere, og tilsidst opnåedes en Overenskomst med Hensyn til Betalingen. Jeg meddelte Martin, at jeg foreløbig ikke vilde optegne Æventyr, men Sange. Næste Dag indfandt han sig; Marc var også tilstede for at „hjælpe“ mig. Denne „Hjælp“ bestod imidlertid $i$, at han uafbrudt sad og skældte Martin ud som en Skoledreng og absolut vilde pånøde mig sine Konjekturer til Martins Sange. Jeg sagde til ham, at han den næste Dag (en Lördag) ikke skulde komme, för Martin var gået. Marc fik sin Betaling i Ugevis, og jeg havde allerede for flere Dage siden sagt til ham, at denne Uge foreløbig skulde være den sidste. Om Lördagen kom altså Martin alene, og jeg nedskrev nogle Sange, ja endogså en kort prosaisk Indledning til en af Sangene. Om Eftermiddagen kom Marc, og vi begyndte nu at gennemgå Sangene. Det blev mig hurtigt klart, at Marc ene og alene bestræbte sig 
for at vise sin uhyre Overlegenhed over Martin, og dette blev Anledning til, at Marc fik en temmelig ublid Medfart af mig og blev grundigt oplyst om, at han havde for höj en Mening om sig selv; min værste Bebrejdelse mod ham var vel den, at han ikke havde meddelt mig de virkelige dialektiske Former, som jeg ønskede at lære at kende, men atter og atter havde trakteret mig med Bogformer til Trods for sine höjtidelige Forsikringer om, at det ikke kunde falde ham ind at meddele mig Usandhed, og om, at han ingen Interesse havde $\mathrm{i}$ at fremstille Dialekten urigtigt for mig. Siden har jeg udelukkende holdt mig til Martin, og gennem en god Del Bryderier har jeg endeligt fået ham dresseret til at diktere Æventyr. Jeg har 8 Æventyr og Halvdelen af det niende, 33 Sange (en Del af dem meget lange) og 47 Småting (Gåder, Ordsprog, Ramser). Dog er der endnu en hel Del at udsætte på Martins Diktat. Når Helten i et Eventyr først får en udførlig Besked om, hvordan han skal bære sig ad, og derefter udfører denne Besked, springer Martin regelmæssig fra den futuriske Besked over til Fortælling i Præteritum. I Begyndelsen tvang jeg ham til at korrigere dette; men det var en uhyre vanskelig Sag; nu gör jeg ingen Modstand mod denne "stilistiske“ Ejendommelighed. Men der er også andre Vidnesbyrd om, at [der] ikke er den Klarhed og Orden $\mathrm{i}$ hans Tanker, som hos min albanesiske Eventyrfortæller. Han har heller ikke endnu helt opgivet den Vane at variere enhver Sætning, som han skulde gentage, hvorved han undertiden nødede mig til 3 eller 4 Gange at strege Sætningen ud og begynde forfra. Men alligevel har han gjort umådelige Fremskridt. Jeg lader ham også undertiden fortælle mig Ting, som jeg blot lytter til uden at optegne dem, og her møder han da midt imellem Æventyrene op med bibelske Fortællinger om Adam og Eva, om Abraham og Isak, om Jesus på Korset, Lignelsen om den barmhjærtige Samaritan. - Jeg læste en Dag et irsk Eventyr for ham; han ledsagede Oplæsningen med de samme livlige Udråb, som en ægte Æventyrfortæller gör Regning på fra Tilhørernes Side, og siden har han fortalt dette Æventyr til Per og Povl, bl.a. også til Præsten. - Det Sprog, Martin taler, står tydeligt nok på et ældre Standpunkt end Marc's, og Marc's Sprog er ældre end min første Hjemmelsmand, Michel Flaherty's. Dette stemmer med de tre Personers relative Alder, men jeg er alligevel ikke lidt overrasket over denne Mangfoldighed; hertil kommer muligvis endogså lokale Forskelligheder; $\mathrm{i}$ en af de vestligste Landsbyer hørte jeg således et stemmeløst $\mathrm{r}$ i de to Ord coirce, „Havre“ og ort „over Dig“ (altså foran k og t), medens jeg ellers kun har hørt et stemt $\mathrm{r}$ i disse Tilfælde; men jeg har endnu ikke undersøgt, hvorvidt dette kan være en individuel Ejendommelighed. 
- Irsk indeholder en större Mangfoldighed af Lyd end noget andet Sprog, jeg hidtil har hørt (6 forskellige l-Lyd o.s.v.). - Jeg bliver rimeligvis $\mathrm{i}$ hele Oktober og måske længere her på Aran, skönt der går flere Penge med, end jeg egentlig havde gjort Regning på. Hvor jeg derefter tager hen, er endnu usikkert.

Det vil næppe vare mere end en Måned, för jeg igen bliver nødt til at bede om en ny Sending Penge, og så kan jeg ved den Lejlighed meddele, hvad jeg ikke har fået omtalt i dette Brev.

Jeg håber, at Professoren befinder sig vel trods det efterårsagtige Vejr vi har haft i den sidste Tid. Jeg beder Dem overbringe min ærbødige Hilsen til Professorinden og Frk. Rasmussen. ${ }^{43}$ )

Holger Pedersen er kommet ind i en nogenlunde rolig arbejdsrytme med Martin, hvad optegnelserne i notesbøgerne tyder på. Men begyndervanskelighederne i samarbejdet mellem dem må have været store, thi også senere nævner Holger Pedersen sit mas med at dressere Martin, f.ex. i anmeldelsen af Finck's Die araner Mundart. ${ }^{44}$ )

Beskrivelsen af Martin og hans hus vendte Holger Pedersen tilbage til mange år senere, da han i Tønder efter Genforeningen holdt et foredrag om Irlands folk. Efter de mange år er de første gnidninger som beskrevet i det foregående brev glemt, og han mindes nu Martin som sin „særlige ven“, som han under Aranopholdet havde et godt og nært samarbejde med. I foredraget fremdrages Martins hus som et exempel på de kummerlige forhold, det irske folk levede under gennem flere hundrede års fremmed overherredømme. Han slutter sin beskrivelse således:

Han var naturligvis fæster og skulde for sit usle jordstykke (eller rettere stenstykke) betale en årlig avgift, der vel ikke $\mathrm{i}$ og for sig var stor; han har nævnt summen for mig, men jeg husker ikke, om det var i eller 2 pund sterling; men den måtte synes altfor stor efter, jordens" (stenenes) bonitet. En del af elendigheden kunde for en overfladisk betragtning synes at skyldes Irerne selv; - - Man får let det indtryk, at Irerne ikke er fortagsomme og når de får penge mellem hænder, er de utroligt letsindige til at give dem ud. Men man må huske på, at deres hele stilling, som den har været under det engelske herredömme, ikke indeholdt nogen opfordring til fortagsomhed eller sparsomhed. Det vilde blot være bleven til fordel for godsejeren. Så hellere lade stå til; om man ikke kunde betale avgiften, var efter den skikkelige gamle Martins udsagn ikke så skæbnesvangert; tilstandene var nemlig efterhånden 
bleven sådan, at godsejeren ikke turde sætte en fæster ud; gjorde han det, fik han det ikke fæstet ud igen; den, der flyttede ind, vilde nemlig risikere at få huset brændt av over hovedet på sig. ${ }^{45}$ )

Det billede, vi får af Martin i Holger Pedersens brev og foredrag, under- og udbygges af de skildringer, Synge og Symons giver af ham.

Synge mødte Martin allerede den første dag under sit Aranophold. Da han om aftenen sidder på sit hotelværelse, hører han ,a shuffling on the stairs, and the old dark man I had spoken to in the morning groped his way into the room. I brought him over to the fire, and we talked for many hours." I den følgende samtale nævner Mourteen, som han hedder her, at han har lært Holger Pedersen irsk. Om sig selv fortæller han, at han ,a little after middle age [...] had fallen over a cliff, and since then $[\ldots]$ had had little eyesight, and a trembling of his hands and head." Synge skildrer, hvorledes Mourteen under samtalen „sat huddled together over the fire, shaking and blind, yet his face was indescribably pliant lighting up with an ecstasy of humour when he told me anything that had a point of wit or malice, and growing sombre and desolate when he spoke of religion and the fairies. He had a great confidence in his powers and talent, and in the superiority of his stories over all other stories in the world." ${ }^{* 46}$ ) Eventyrfortælleren, der fortæller sine historier „i en ustandselig Fart under den livligste Gestikuleren“ til stor gene for Holger Pedersen, der jo samtidig skulle skrive dem ned, møder vi også i Synge's beretning. Under deres udflugter på Aran fortæller Mourteen eventyr, og Synge beskriver, hvilket indtryk det gør på ham. Under et besøg i de ruiner, som også Holger Pedersen omtaler, beretter Synge, hvorledes Mourteen ,sat down in the middle of the floor and began to recite old Irish poetry, with an exquisite purity of intonation that brought tears to my eyes though I understood but little of the meaning. ${ }^{\text {"47 }}$ ) Martins minespil er som i deres første samtale også ved senere lejligheder genstand for Synge's opmærksomhed. Han nævner et sted, hvorledes Martins ,old face puckered with a gleam of pagan malice" og hvorledes han, mens Martin fortæller ham et timelangt eventyr, følger hans minespil og næsten glemmer at lytte til historien:

He is so blind that I can gaze at him without discourtesy, and after a while the expression of his face made me forget to listen, and I lay dreamily in the sunshine letting the antique formulas of the story blend with the suggestions from the masonry I lay on. The glow of childish transport that came over him when he reached the nonsense ending - so 
common in these tales - recalled me to myself and I listened attentively while he gabbled with delighted haste $\ldots{ }^{48}$ )

Ogsă Arthur Symons mødte den halvblinde ivrigt gestikulerende Martin. Han nævner ham dog ikke ved navn, omtaler ham blot som ,a professionel story-teller" og beskriver ham som „half blind of a wild appearance; a small hairy man, all gesture, and as if set on springs, who spoke somewhat broken English in a roar." Efter at han har fortalt Symons og hans ledsagere nogle historier, nævner han også denne „Dane“, som var kommet til øen for at lære irsk, og som „knew all the languages, the Proosy and the Roosy, and the Span, and the Grig. ${ }^{\text {" }}{ }^{49}$ )

\section{Hr. Professor Ussing!}

Jeg takker Dem for Deres Brev med de deri indeholdte Meddelelser, og Tak for Deres aldrig udeblivende Omsorg for mig. Jeg tror nu egentlig, at jeg nok kunde komme ud af det med de Penge, jeg allerede havde, uden at beholde det Hopnerske Stipendium, men det vil naturligvis være til Gavn for mine Studier at have så meget rigeligere Midler, eventuelt kan jeg jo opgive Stipendiet efter at have hævet det i December Termin.

Jeg har siden sidst fortsat mine nyirske Studier på samme Måde som tidligere. Just idag begyndte jeg at optegne et milelangt Æventyr om Kongens Sön af Erin og Kongens Sön af Lochlann. Begge disse Kongesönner er drabelige Helte, men det synes dog, at den irske Prins er Nummer ét. I et andet Eventyr, jeg har optegnet, optræder en Prinsesse af Lochlann, så at man sér, at dette Land spiller en betydelig Rolle i den irske Folkefantasi. - En Ejendommelighed ved de irske Æventyr er deres formelagtige Præg. Der forekommer lange faststående Ramser i dem. Beskrivelser af Sejlads, af Kamp med Uhyrer o.s.v. o.s.v. Jeg kalder disse Beskrivelser Ramser, da de ofte består af meningsløse allitererende Ord og andet Klingklang eller af forældede Ord, som Eventyrfortælleren selv næppe forstår. Disse Ramser er naturligvis udsatte for de samme kuriøse Fordrejelser som Sange, der overleveres mundtligt. En af de Sange, jeg har optegnet, genfandt jeg i en trykt Samling „folklore“ og der forekom deri den Linje: „Pak Dig herfra i en Fart (air luathas) og gå hjem.“ Martin havde derimod meddelt: „Smid Asken (an luaith) ud og gå hjem“, og dette syntes motiveret ved den foregående Linje: ,Jeg mødte Síoguidhe mac Cruach, han var mørk og barsk og Arnen var kold." Istedenfor dette stod der i den trykte Samling: „Han var mørk og barsk, og hans Vrede var stor." Et enkelt 
Ord er blevet misforstået, og derefter den øvrige Del af Verset omformet; dette Fænomén er mig også bekendt fra Albanesisk. Disse mærkelige variae lectiones forekommer også $\mathrm{i}$ de faststående Beskrivelser $\mathrm{i}$ Eventyrene. - Denne Forkærlighed for allitererende Skvalder genfindes i den aldre irske Literatur; den spiller en mindre Rolle i de aldste Tekster (den såkaldte Cuchulinnsagnkreds), men griber efterhånden om sig samtidig med, at Literaturens eget Værd forringes; dette er Tilfældet i de Tekster, der drejer sig om den yngre irske (og som bekendt også skotske) Sagnkreds (Finn-Kredsen, eller Ossian-Kredsen efter Finns Sön Oisín). Om denne yngre Sagnkreds påstår Prof. Zimmer - og han har udførlig søgt at påvise det -, at den har en skandinavisk Baggrund, under alle Omstændigheder har han sikkert Ret i, at en god Del af de forekommende Navne er Omformninger af nordiske Navne. Denne Sagnkreds har levet til den Dag idag. Da Martin en Dag i en Sang dikterede mig Navnet Ešin, blev han meget forbavset over, at jeg ikke vidste, hvem denne Ešin var: jeg genkendte ikke straks heri Navnet Oisín (Ešīn er den regelmæssige nyirske Udtale $-\mathrm{s}=$ eng. sh - af Oisín). Minder fra den ældre Sagnkreds, Cuchulinn-Kredsen, er ikke talrige. I et af Eventyrene forekommer dog Irlands berømte Overkonge Conchobar i en ynkelig reduceret Skikkelse: en tapper Helt, der dræber de frygteligste Uhyrer, men yderlig fattig: han ejede ingen Jord, men hele hans Formue bestod $\mathrm{i}$ to Får, som han havde Ret til at lade græsse omkring i Landsbyen. Også Navnet er ret grundigt forandret; han hedder „Krochūr med de to Får". Dog er Krochūr (eller som den yngre Generation her på Aran vilde sige, med en tilsyneladende ældre Lydform: Knochūr) den fuldstændig regelmæssige nyirske Udtale af Conchobar, og til Overflod angav Martin selv, at "Krochür" var "Connor". Connor er den engelske Form af Navnet, der er i Brug som Efternavn den Dag idag.

- Iøvrigt indeholder Eventyrene de samme Træk som Folkeeventyrene $\mathrm{i}$ adskillige andre Lande af Evropa (f.Eks., for at holde mig til min egen Erfaring, i Litaven, i Rusland, i Albanien, i Danmark); de er ingenlunde finere end de albanesiske Eventyr. Jeg har både på Albanesisk og på Irsk optegnet et Æventyr, der svarer til det danske om „Lille Klavs og store Klavs". Heri forekommer jo bl.a. det Træk at "store Klavs" vil dræbe ,lille Klavs", men ved et Tilfælde kommer hans Overfald til at gå ud over den gamle Bedstemoder, der netop Dagen i forvejen var død, og lille Klavs tjener derefter Penge ved at bilde forskellige Personer ind, at de har dræbt Bedstemoderen, og ved at true dem med Straf. Allerede dette er jo lovligt plumpt, endskönt den danske 
Version har været så ömfindtlig, at den lader Bedstemoderen dø i forvejen. På Irsk er det anderledes: De to ældre Brødre kommer hjem fra Markedet, efter at den yngre Broder har spillet dem et slemt Puds; de aftaler at hævne sig ved om Natten at gå til Broderens Hus og vælte Gavl-Væggen ned over Sengen, hvor han sover tillige med Kone og Börn. Den yngre Broder lurer bagved et Stendige, og erfarer således, hvad der er i gære. Han kommer hjem og lader som intet. „Det er koldt iaften, Moder," siger han til sin gamle Moder, der levede i hans Hus. "Ja, det er koldt, Sön," svarer hun. „Du skal sove i min Seng inat; Du vilde dø af Kulde i din egen Seng; jeg og min Kone og Börnene er unge og kan tåle Kulden.“ Moderen lægger sig i Familiesengen, („og han lægger Dynen tilrette over hende"), og Börnene sendes op i Bedstemoderens Seng. Derefter indvier Manden sin Kone i Sagens Sammenhæng. Om Natten ankommer de to ældre Brødre, vælter Væggen, og dræber den gamle Kone. Den efterfølgende Dag afpresser Manden ikke blot sine to Brødre store Pengesummer, men gör det samme overfor forskellige andre Personer, hvem han indbilder, at de har dræbt hans Moder. Brødrene ser den store Rigdom, der er kommen tilhuse hos ham, og spörger ham om, hvor han har fảet det fra. ,Jeg kom gående med min gamle Moder - jeg havde ikke Råd til at købe en Ligkiste -; jeg mødte en Mand, der sagde, at jeg skulde bringe hende til Markedet; der var en rig Mand fra England (Sasana, egentlig 'Saksernes Land'), der købte Lig af gamle Koner for at male Knoklerne til Mel. Jeg bragte hende på Markedet og fik 6ooo Pund Sterling for hende." Da Brødrene hørte det, skyndte de sig hjem og sendte Bud efter alle gamle Koner i Omegnen under Påskud af, at de skulde være dem behjælpelige med at „banke Hör“. De dræbte dem og kørte næste Dag til Markedet med to Vognlæs af de gamle Koner. På Markedet går det dem ikke godt, men da de vil hævne sig, spiller den yngre Broder dem endnu et tredie Puds og narrer dem til at lade sig indsy i Sække og kaste i Havet i Forventning om at finde store Hjorder af Kvæg på Havbunden. - Dette er unægtelig en temmelig grovkornet Skæmt; jeg kendte hidtil ikke dette Eventyr i så plump en Skikkelse. Mærkeligt nok indledes dette Eventyr med en Skildring af, hvor hårdhjærtede de to ældre Brødre var; de jog den gamle Moder ud af deres Hus, så at hun måtte gå og tigge. Den yngste broder, som er fattig - de to ældre er rige -, tager sig nu af Moderen: „Det var ikke smukt, Din Sön behandlede Dig, efter alt, hvad Du har gennemlevet; men nu skal jeg ikke lade noget ondt komme Dig nær, så længe jeg lever."

- Mit egentlige Ærinde er denne Gang at bede Dem om at tilsende 
mig 5 Pund Sterling ( stor Sum, da man ikke véd, hvor store Udbetalinger, det herværende Posthus kan præstere; dog kan det sikkert nok udbetale indtil 8 Pund Sterling eller mere; så hvis Professoren skulde ansé det for hensigtsmæssigere at sende $7^{1 / 2}$ eller 8 Pund, vilde der ikke være noget i Vejen for det. Så vidt jeg har kunnet erfare, er der ikke nogen Hindring for at sende Penge hertil ved Postanvisning.

- Jeg lykønsker Professoren til at blive fri for at rette dårlige latinske Stile m.m., så De for Fremtiden kan dyrke Deres Videnskab efter Deres eget Hjærtes Trang, og forhåbentlig endnu i en lang Årrække bidrage til denne Videnskabs Fremgang. ${ }^{50}$ ) Det gör mig ondt, at Professorinden ikke befinder sig vel; jeg vil ønske, at Udsigten til den interessante Rejse i Foråret må göre det lettere for hende at komme igennem Vinteren, og at De begge må tiltræde den Rejse med godt Helbred. Min arbødige Hilsen til Dem og Deres Familie. ${ }^{51}$ )

Professor Ussing anså det åbenbart for hensigtsmæssigere at sende så stort et beløb som muligt. Holger Pedersen takker prompte for beløbet tilligemed en redegørelse for sit arbejde, der viser, at han nu er begyndt af bearbejde det indsamlede materiale:

Jeg takker Dem for 'Tilsendelsen af de 8 Pund Sterling, som Jeg idag har modtaget. Det vil endnu vare nogle Uger, om ikke mere, förend jeg kan tænke på at forlade Aran; jeg har længe været beskæftiget med at udarbejde en grammatisk Beskrivelse af Dialekten; af Lydlæren og Formlæren har jeg Hovedtrækkene på Papiret og tilføjer daglig nyt Materiale; jeg må derefter tage fat på Syntaksen, og jeg må ligeledes udarbejde et Glossar. Min Eventyrfortæller Martin gör meget god Tjeneste; han er istand til at rette selv meget små Fejl i Udtalen; netop idag havde jeg et Eksempel derpå; enhver Konsonant har i Irsk en dobbelt Udtale, mouilleret og ikke mouilleret; de irske Grammatikker angiver én Undtagelse fra denne Regel; Læbelydene (p, b, m, f) skal ikke mouilleres; én af de forste Iagtagelser, jeg gjorde her, var nu imidlertid, at denne Undtagelse ikke gælder; også Læbelydene kan mouilleres; i min Nedskrivning betegner jeg de mouillerede Lyd $p^{\prime}, b^{1}$, $\mathrm{m}^{1}, \mathrm{f}^{1},\left(\mathrm{t}^{1} \mathrm{~d}^{1} \mathrm{k}^{1} \chi^{1} \gamma^{1} \mathrm{~g}^{1}\right.$ o.s.v.); på denne Måde betegnes disse Lyd $\mathrm{i}$ den polske Retskrivning (Irlænderne betegner i Skriftsproget Mouilleringen ved Hjælp af et i eller e foran og efter Konsonanten, f.Eks. cailleach eller

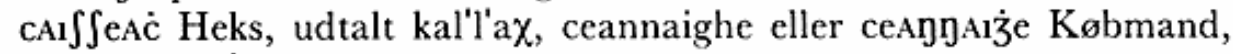
udtalt k'anní; alt eller A $\mathrm{A} \tau$ udtalt ałłt er Singularis 'Led(joint)' Pluralis 
er ailt Al' $\tau \tau$ udtalt al'l't'; - i det første Eksempel er Mouilleringen betegnet ved en Hjælpevokal foran og efter Konsonantgruppen, i det andet Eksempel kan der af gode Grunde kun anbringes én Hjælpevokal, nemlig efter Begyndelseskonsonanten, og i det tredie Eksempel kan der ligeledes kun anbringes én Hjælpevokal, nemlig foran Slutningskonsonanterne). Forskellen mellem $p$ og p', b og b' o.s.v. er nu i mange Tilfælde yderst vanskelig at høre; i sådanne Tilfæelde har Martin gentagne gange på sin naive Måde (han kan jo hverken læse eller skrive) gjort opmærksom på Forskellen, og bl.a. gjorde han idag opmærksom på Forskellen mellem b og b'. Denne dobbelte Udtale af enhver Konsonant må have været tilstede allerede i Oldirsk; thi Mouilleringen er for Slutningskonsonanternes Vedkommende bevirket af en udlydende Vokal, der var falden bort længe, för de ældste irske Manuskripter skreves. Når det hedder Sing. alt, Plur. ailt, så er det Resultatet af den bortfaldne Pluralendelse i , sml. lat. Plur. dominī. Det er derfor klart, at Mouilleringen må have været tilstede i Oldirsk, men den oldirske Orthografi lader ofte Mouilleringen ubetegnet; efter a vilde den blive betegnet, men ikke f.Eks. efter i; i Oldirsk vilde man skrive fir 'sand' både i Nominativ og i Genetiv Singularis Masc., men i Nyirsk hedder Nom. fior $\mathrm{F}^{\text {ior (udt. fir) }}$

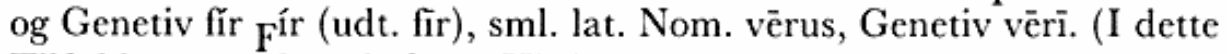
Tilfælde anvendes altså en Hjælpevokal til at betegne Fraværelse af Mouilleringen).

Mouilleringen fordoblede Konsonanternes Antal; men de blev ligeledes fordoblede af en anden Overgang, der fandt Sted i den fælleskeltiske Periode og beror på Lydforhold, som for længe siden var forsvundne, förend de ældste irske Manuskripter skreves. Denne Overgang bærer Navnet Aspiration, og den består i, at en Konsonant mellem to Vokaler blev udtalt med en løsere (åbnere) Stilling af Taleorganerne end under andre Omstændigheder. Derved blev $\mathrm{k}$ til en Lyd $=$ nygræesk $\chi$ (eller tysk ch), g til $\gamma, \mathrm{b}$ til $w, \mathrm{~m}$ til et $w$ udtalt gennem Næsen (w) o.s.v. I Oldirsk vidste man ikke, hvordan man skulde betegne alle disse Lyd ved Hjælp af det latinske Alfabet; det aspirerede $k, t \operatorname{og} p$ (nu udtalt $\chi, h$ og f, men oprindelig rimeligvis $\chi, \mathrm{p}$ og $\mathrm{f}$ ) betegnede man med $\mathrm{ch}, \mathrm{th}, \mathrm{ph} \mathrm{i}$ Tilslutning til latinsk Gengivelse af græske Ord, og de øvrige aspirerede Lyd lod man være ubetegnede. I Nyirsk blev der rådet Bod på denne Unöjagtighed ved Indførelsen af Tegnene bh, dh, gh og mh, og man fandt på at ombytte h'et med en Prik over Bogstavet, så at man nu skriver ch eller sædvanligvis $\dot{\mathrm{c}}$, th eller $\dot{\mathrm{t}}$, ph eller $\dot{\mathrm{p}}$, bh eller $\mathrm{b}$, dh eller $\delta$, gh eller $\dot{\mathbf{3}}$ og mh eller $\dot{\mathrm{m}}$ (Irlænderne bruger nemlig sædvanlig en Afart af det latinske Alfabet, noget lignende som den tyske Afart deraf). Men i 
to Tilfælde er Aspirationen den Dag idag ikke kommen til Udtryk: det uaspirerede og det aspirerede $\mathrm{l}$ og $\mathrm{n}$ skrives i de fleste Tilfælde ens; kun nogle enkelte Forfattere har gjort et Forsøg på at indføre Tegn for disse Lyd, der endnu den Dag idag anvendes i Folkesproget i skönneste Overensstemmelse med Lydenes Omgivelser i det indoeuropæiske Grundsprog. - Jeg vil blot anføre nogle Eksempler på Aspiration i Forlyd: a ceann A ceAn udt. ă k'ānn betyder 'hendes Hoved', a cheann

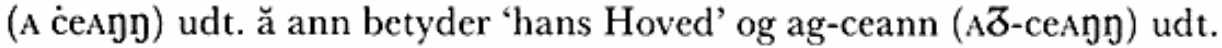
ă g'ānn betyder 'deres Hoved' [dette sidste Tilfælde betegnes sædvanlig med Navnet Eklipse, men er, som jeg agter at påvise i et af mine næste Arbejder, kun et særlig Tilfælde af Aspiration]; denne Forskel beror på,

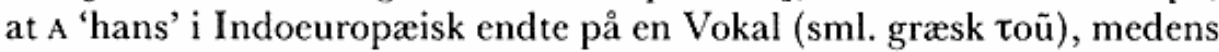
A 'hendes' endte på s (sml. græsk tĩs) og A 'deres' endte på en Nasal (sml. græsk $\tau \tilde{\omega} \mathrm{v})$; - et andet Eksempel: snáithe udt. snā 'en Tråd', dá shnáithe ( $\delta \dot{A}$ ṡ̉ajte) udt. dầ ňă ( $\breve{n}=$ stemmeløst $n$ ) betyder 'to Tråde'

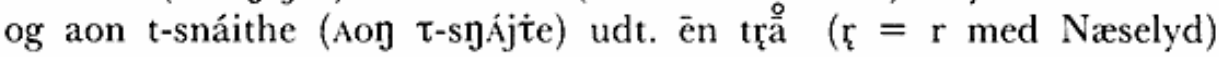
betyder 'én Tråd'; dette sidste Tilfælde (Overgangen fra $s$ til t) er ligeledes et specielt Tilfælde af Aspiration; - et tredie Eksempel: bean (beAg) udt. b'an betyder 'Kvinde' a bhean (A b eAj) udt. ă v'an betyder 'hans Hustru' og aig an m-bean (AJ3 m-beAj) udt. eg ă man betyder 'hos, til Kvinden'. Kort sagt: Begyndelseskonsonanten i ethvert irsk Ord kan i Reglen antage tre forskellige Lyd; den eneste uforanderlige Konsonant er $\mathrm{r}$ (men i Kymrisk kan også $\mathrm{r}$ modtage den Modifikation, der svarer til Aspiration i Irsk). Hvad jeg her har anført om den nyirske Orthografi vil være et Eksempel på, at dette Sprog på en meget væsentlig Måde supplerer Oldirsk ved Sprogsammenligning. Min ærbødige Hilsen til Dem og Deres. ${ }^{52}$ )

Det følgende brev er udateret, men må formentlig være skrevet engang sidst i november eller $\mathrm{i}$ begyndelsen af december. De tekster, Holger Pedersen i dette efterår optegnede, er så godt som alle omhyggeligt daterede med angivelse af kilde. Man kan i notesbøgerne følge arbejdet, der skrider støt frem med Martin som bogstavelig talt eneste kilde fra onsdag den 2. oktober hver dag mandag til lørdag. De seneste, daterede tekstoptegnelser er fra den I 9 . november. Derefter er han, som han siger, gået igang med indsamlingen af dialektens ordforråd, som han så har ordnet $\mathrm{i}$ ordbogsform..$^{53}$ )

Hr. Professor Ussing!

Den mig af Prof. Ribbeck ${ }^{54}$ ) tilsendte Kvittering for Honoraret for mine 
'Alb. ' ('exter', ${ }^{55}$ ) har jeg idag sendt tilbage forsynet med min Underskrift og ledsaget af den Anmodning, at Pengene må blive sendte til Dem. Jeg beder Dem derfor om, at De vil have den Godhed at modtage disse Penge på mine Vegne. - Jeg er optaget af at samle denne Dialekts Ordforråd igennem irske Samtaler om Agerbrug, Kvægavl, Mælkeri, Fiskeri o.s.v. o.s.v. Jeg foretager Spadsereture ledsaget af Martin for at tale med Folk og aflægger Besøg hos alle Øens Håndværkere (Skrædder, Væver, Skomager, Smed, Bødker, Snedker er hele Listen), optegner også nogle Ting efter andre Kilder end Martin. Herom vil jeg fortælle næste Gang. Min ærbødige Hilsen til Dem og Deres. ${ }^{56}$ )

December måned brugte Holger Pedersen da øjensynlig til at ordne sit materiale. Her $\mathrm{i}$ de sidste dage af året synes han at være klar til at gøre status over sit arbejde. Juleaften sætter han sig så til at skrive et langt brev til professor Vilhelm Thomsen ( $184^{2-1} 927$ ). Efter en redegørelse for nogle sproglige problemer, der er langt mere detailleret end de redegørelser, han normalt har sendt til professor Ussing, slutter han af med nogle lidt mismodige bemærkninger om de almindelige forhold på øen. Hvad enten det skyldes hjemve eller overtræthed efter måneders slid, som nu er ved at være til ende, synes han i hvert fald pludselig grebet af en juledepression. Brevet er bevaret blandt Vilhelm Thomsens papirer $^{57}$ ):

... Med Hensyn til de almindelige Forhold her på Aran kan jeg ikke just sige, at jeg er henrykt over Beboerne. De inddeler hårdnakket alle Mennesker $\mathrm{i}$ to bestemt adskilte Klasser; daoine uaisle 'fornemme Mænd' og dem selv. daoine uaisle menes at have Penge „så tykt som Törvesmuld". Enhver Fremmed bliver henregnet til daoine uaisle, og enhver Aranboer betragter det som sin Pligt efter Evne at bidrage til at udplyndre ham. At nogen ubetalt skulde interessere sig for mit Foretagende (således som det i stort Mål var Tilfældet blandt Albaneserne), er absolut udelukket. Men der er jo også Forskel på Sydens blå Himmel og disse stormpiskede Klipper, hvis Beboere ovenikøbet bliver ubarmhjærtigt udsugede af Jordherren. Min Eventyrfortæller Martin, der bor i en Hytte, som næppe en Hund vilde tage tiltakke med i Danmark, og som på sin Jordlod næppe nok kan holde to Får og to Æsler til at bjærge Tang og ikke kan avle så mange Kartofler, at han kan „,brød“-føde sig selv, betaler 2 Pund Sterling $\mathrm{i}$ årlig Afgift af sin Jord. Under disse Forhold kan man ikke undre sig over, at Beboernes Interesse ikke når höjere end til Begrebet „Penge“. Jeg var fortrydelig over, at jeg i 
Albanien skulde betegne mine Sprogstudier som en sevdá „Kærlighed“, eftersom enhver Kæphest betegnedes med samme Navn; men her på Aran vilde jeg være glad, om Beboerne kunde hæve sig til dette 'sevdá'Standpunkt. Men de er allesammen fast overbeviste om, at jeg kan "sælge" de Ting, jeg her optegner, og blive en rig Mand derved. Her at drømme om Grækernes Begejstring for $\dot{\varepsilon} \pi i \sigma \tau \eta \dot{\mu} \eta$ vilde være latterligt.

Hermed sender jeg Dem mine bedste Ønsker for det nye År, i det Håb, at Deres Helbred må gå fremad for hver Dag i det ny Ár, til Glæde først og fremmest for os Studerende, men tillige til Glæde for alle dannede Danske. ${ }^{58}$ )

Holger Pedersens sidste brev fra Aran er til professor Ussing med tak for endnu $£ 8$, der åbenbart skal klare hans resterende udgifter her samt hans rejse tilbage til Dublin. Men til det sidste har han besværligheder at slås med:

Jeg takker Dem for de tilsendte 8 Pund Sterling. Jeg modtog igår den i London udstedte „Money Order"; Postmesteren har imidlertid endnu ikke modtaget den dertil svarende „Advice“, så at jeg foreløbig ikke kan få Pengene udbetalt. Det er selvfølgelig en Uorden, at denne „Advice“ ikke er ankommen samtidig med den pågældende „Money Order“; Postvæsenet i London synes ikke at være særlig udmærket. Men för eller senere må jeg jo få Pengene. Jeg må bede Professoren undskylde, at jeg ikke denne Gang skriver noget udførligt Brev. Om 14 Dage agter jeg at forlade Aran.

I Håb om, at Deres og Professorindens Helbredstilstand må gå fremad, ønsker jeg Dem et glædeligt Nytår. ${ }^{59}$ )

I begyndelsen af det nye år forlader Holger Pedersen Aran efter godt 4 måneders ophold. Mens han i Galway venter på tog til Dublin, skriver han igen til Ussing og gør som sædvanlig omhyggeligt rede for sit arbejde og sine planer.

Hr. Professor Ussing!

Jeg har nu forladt Aran og befinder mig i dette Öjeblik i Jærnbanchotellet i Galway på Vejen til Dublin. Med Hensyn til Resultatet af mine Studier i Aran kan jeg sige følgende: jeg har en Ordsamling på 3000 Ord, og denne Samling kan jeg endnu forøge adskilligt ved at gennemgå mine Tekster. Tillige har jeg et ordnet Materiale såvel for Lydhistorien som for den egentlige Grammatik. Jeg vil nu i Dublin skaffe mig en 
Oversigt over den nyirske Literatur: det er nemt gjort, for der er så godt som ikke andet, end hvad jeg allerede kender og har benyttet. Ossianske Digte eller tilsvarende Prosafortællinger kan kun i Ordets videste Betydning regnes med til den nyirske Literatur, thi de er skrevne i et kunstigt antikveret Sprog, der ifølge en Naturnødvendighed vrimler af Uformer, som aldrig har været til. Da tilmed Indholdet er interesseløst, vilde man kun spilde sin Tid ved at læse et större Kvantum af disse miserable Udløbere af den mellemirske Literatur istedenfor at vende sig til den mellemirske Literatur selv. Den virkelig nyirske Literatur består med et Par Undtagelser udelukkende af religiøse Bøger. Fra Dublin har jeg isinde at vende tilbage til Greifswald. At give mig til at studere andre nyirske Dialekter vilde være et ufrugtbart og kostbart Arbejde, hvortil mine Penge slet ikke vilde slå til. Det er meget bedre at benytte den korte Tid, jeg endnu har tilbage, för jeg skal tage fat på Brødslidet, ${ }^{60}$ ) til at erhverve mig de uundværlige Kundskaber i Oldirsk, Mellemirsk, Kymrisk og Bretonsk. Gör jeg ikke dette nu, så er det et Spörgsmål, hvornår jeg får det gjort. Prof. Zimmer er villig til uafbrudt (også $\mathrm{i}$ Påskeferien) at holde Øvelser i de forskellige keltiske Sprog med mig og den unge Welshman (Mr. William), som for Tiden opholder sig i Greifswald. Den daglige Omgang med denne sidste vil være den bedst tænkelige Lejlighed til at lære den nykymriske Udtale at kende, meget bedre end mit fra først af påtænkte I $_{4}$ Dages Ophold i Wales. Ifølge disse Overvejelser vil jeg efter det nødvendige Ophold i Dublin tage i lige Linje over Grimsby til Hamburg og Greifswald. Dertil behøver jeg imidlertid Rejsepenge. Ved min Afrejse fra Greifswald udrustede jeg mig med 4 oo Reichsmark; den samme Sum vil være nødvendig denne Gang til at bestride en Del Bogindkøb i Dublin samt Rejsen og de første Udgifter i Greifswald. På denne Måde har min Irlandsrejse kostet $7 \mathbf{I}$ Pund Sterling, men jeg gad nok se, hvem der i mit Sted kunde have gjort det billigere. Det er dog langt fra, at jeg mener, at Rejsen har været for dyr, thi jeg hjembringer et aldeles nyt sproghistorisk Materiale, der har åbnet mine Öjne for Masser af vigtige Kendsgærninger, som jeg tidligere ikke anede. I det Håb, at De vil billige min Rejseplan, beder jeg Dem altså om at sende mig 20 Pund Sterling. Det gör mig ondt, at jeg så ofte gör Dem Ulejlighed i denne Vinter, da Deres Helbred gör Ro nødvendig for Dem. 
Jeg beder Dem adressere Pengesendinger til

Holger Pedersen

Crown Hotel

18 Upper Sackville Street

Dublin

Hermed de bedste Ønsker for Deres og Professorindens Helbred. ${ }^{61}$ )

Pengene kom, og Holger Pedersen takkede:

Hr. Professor Ussing!

Jeg takker Dem for de tilsendte 2o Pund St. (og I Penny), som jeg idag har modtaget. Da jeg igår har tilendebragt mit Arbejde i det herværende Bibliothek, vil jeg kunne afrejse herfra enten iaften eller imorgen tidlig, men det vil jo vare 3 eller 4 Dage, för jeg når Greifswald.

Jeg aflagde i Söndags et Besøg hos Professor Atkinson (Professor for sammenlignende Sprogvidenskab). Han gav mig Særtryk af nogle Afhandlinger, hvoraf to handlede om Irsk, én om Kymrisk og én om Koptisk! ${ }^{62}$ ) Atkinson er en meget lærd og dygtig Sprogforsker. Da jeg ytrede den Hensigt at skrive en Fremstilling af den såkaldte Aspiration i Irsk med Benyttelse af mit nyirske Materiale, tilbød han at supplere de vedkommende Forhold fra Munster-Dialekten. Han er nemlig i Besiddelse af omfattende Samlinger for denne Dialekt, der afviger mere fra det nordlige Irsk (hvortil Aran hører), end det nordlige Irsk afviger fra Skotsk Gælisk. Muligvis har Atkinson gjort dette Tilbud nærmest for at meddele, at han besidder sådanne Samlinger. Hvis det virkelig er ment, kan det være af megen Nytte for mig.

Atkinson er den eneste Mand i Irland, som har et historisk Kendskab til Irsk. De Mænd, der beskæftiger sig med den praktiske Opgave at bevare (eller endogså et genopvække) det irske Sprog, viser ofte en rent ud uanstændig Mangel på Kundskaber og er tildels af en meget utålelig Art. Skönt jeg er et meget fredeligt Menneske, har jeg ikke kunnet undgå at lægge mig ud med en af disse Herrer (Russel, som i Sommer gjorde sig latterlig i det franske Tidsskrift Revue celtique).$^{63}$ )

Jeg er glad over, at Professoren nu befinder sig bedre, og ønsker, at det samme også må gælde Professorinden. Det kan næppe siges at være nogen bekvem Tid til at flytte fra Regensen i April Måned, förend Foråret rigtigt er kommet. - Selv om Regensen, som De spår, vil blive glad ved den ny Regensprovst, ${ }^{64}$ ) er det sikkert, at der vil blive Sorg over, at De forlader Regensen.

Hvad mine Sager angår, vil jeg være Dem taknemmelig, om De, som 
De skriver, vil bevirke, at de kan blive stående på Regensen. Min ærbødige Hilsen til Dem og Deres. ${ }^{65}$ )

Holger Pedersens optegnelser fra Aran (folkeeventyr, sange og gåder) har aldrig været udgivet. Materialet udmøntede han i sine sproglige behandlinger af keltisk sprog. Det værdifulde folkloristiske materiale, der findes i notesbøgerne, er nu under udgivelse i form af en kommenteret tekstudgave ved cand.phil. Ole Munch-Pedersen.

Holger Pedersen vendte aldrig tilbage til Aran, skønt han en enkelt gang var i Dublin for at holde forelæsninger. Han omtaler flere gange disse ,forelæsninger ved School of Irish Learning ${ }^{(66}$ ). Men hans interesse for øerne og deres beboere synes at have holdt sig. Da Louis Hjelmslev ( $1899-1965)$ var på en rejse til de britiske øer og også drog til Aran, fremgår det af et brev, som han fra sit hotel i Kilronan sendte til Holger Pedersen, at denne har spurgt til forskellige personer. Hjelmslev svarer, at så vidt han har kunnet erfare, var de alle døde. Af Holger Pedersens gamle bekendte var der nok kun havet og klipperne tilbage ${ }^{67}$ )

\section{NOTER}

(1) NkS 2718, fol. - (2) Selvbiografi - NkS 2718, fol. kapsel 37, samt en kortere version trykt i Acta Jutlandica. Vol. XIX. Aarhus 1947, p. $4^{1-42 .}-$ (3) Karl Brugmann $\left(1849^{-19} 19\right)$ var fra 1887 til sin død professor $\mathrm{i}$ indogermansk sprogvidenskab. Hans hovedværk Grundriss der vergleichende Grammatik der indogermanische Sprachen. Strassbourg 1886-92, kom i en ny bearbejdet udg. 1897-19o6 og var således under udarbejdelse under Holger Pedersens studieophold i Leipzig. - (4) August Leskien (1840-1916) studerede klassisk filologi i sin fødeby Kiel og derefter i Leipzig. Under et studieophold i Jena gik han i gang med studiet af sammenlignende sprogvidenskab og slaviske sprog. I 870 vendte han tilbage til Leipzig, hvor han fra 1876 bestred professoratet i slaviske sprog. - (5) Selvbiografi (2) p. $4^{1-42}, \ldots$ en udenlandsrejse ... førte mig til Leipzig, hvor jeg studerede hos Karl Brugmann, A. Leskien o.fl. og skrev min avhandling „Das indogermanische s im Slavischen“." Trykt i Indogermanische Forschungen Bd. 5. Strassbourg 1895 , p. 33-87. - (6) Selvbiografi (2) p. 42. Frugten af dette ophold var bl.a. hans Albanische Texte mit Glossar. Leipzig i 893. (= Abhandlungen der philos.-histor. Classe der Königlichen Sächsischen Akademie der Wissenschaften, 15:3). - (7) Heinrich Zimmer (1851-1910). En rakke af hans vigtigste afhandlinger er publiceret i Zeitschrift für vergleichende Sprachforschung og Zeitschrift für celtische Philologie. For Zimmers bidrag til specielt irsk, se R. I. Best: Bibliography of Irish Philology and Printed Irish Literature. Dublin 1913, og Bibliography of Irish Philology and Manuscript Literature: Publications 1913-1941. Dublin 1942. - Til 2. udg. af Salmonsens Konversationsleksikon skrev Holger Pedersen en rakke artikler om tidens sprogforskere. Artiklen om Zimmer slutter med følgende rørende skildring af 
dennes sidste år, da Zimmer var blevet professor i keltisk filologi i Berlin: „I Aaret 1903 ødelagde en Ildebrand hele Z's Bibliotek, medens han selv opholdt sig langt fra Berlin for at søge Helbredelse for en dyb Nevrasteni, hvoraf han var blevet angrebet. Han overvandt denne frygtelige Ulykke og fortsatte sin Produktion; men Sygdommen vendte senere tilbage og voldte hans Død.“ (Bd. 25. Kbh. 1928, p. 6i 5 ). - (8) Selvbiografi (2) p. 42, samt brev til J. L. Ussing, dat. 12/ 1 1896. - (9) Efter Ussings ded i 1905 blev hans selvbiografi udgivet af hans sønner: Af mit Levned. Kbh. 1906. - (10) Af mit Levned (9), p. 186-87. samt Aarbog for Kiøbenhav'ns Universitet. Meddelelser for det akademiske Aar 1895-96, p. 104-05. - (11) Af mit Levned (9), p. 173-74. - (12) Ripenserbladet. 4. Bd. no. 6. 1952, p. 40-43. - (13) Selvbiografi (2), p. $4^{2}$. I en fødselsdagssamtale i $195^{2}$ navner Holger Pedersen igen dette tilbud og siger, at det var Vilh. Thomsen, der frarådede ham at tage imod det: „Kort tid efter min hjemkomst modtog jeg et tilbud om et schweizisk professorat. Jeg viste det til Vilh. Thomsen, men han vrissede og sagde: „Nxh - tag ikke den stilling, De faar jo ikke mere end en dansk professor.“ Dertil svarede jeg blot: ,Ja, men jeg er ikke dansk professor, og ingen har endnu tilbudt mig et professorat herhjemme." Det er eneste gang, jeg har set Vilh. Thomsen stillet til vags, men han tog det med et smil." (Ekstra Bladet, 4.4.1952). (14) Hans Henriksen: Bibliographie des publications, i: Mélanges linguistiques offerts à M. Holger Pedersen à l'occasion de son soixante-dixième anniversaire 7 avril 1937 . Aarhus 1937, p. IX-XXVIII. - Hans Henriksen: Holger Pedersen - a comprehensive Bibliography of his Writings, ed. and rev. by Konrad Koerner, i: Amsterdam Studies in the Theory and History of Linguistics. Series III. Studies in the History of Linguistics. Vol. 7. Holger Pedersen: A Glance at the History of Linguistics with Particular Regard to the Historical Study of Phonology, translated from the Danish by Caroline C. Henriksen. Amsterdam i 983 , p. XXIII-XXX. - (15) R. Henebry (1863-1916). Hans disputats: A Contribution to the Phonology of Dési-Irish to Serve as an Introduction to the Metrical System of Munster Poetry. Greifswald 1898 , anmeldte Holger Pedersen i Indogermanische Forschungen, Anzeiger Bd. XI. Strassbourg I90o, p. 111. (16) Selvbiografi (2). - (17) NkS 2718, fol. Afd. X: Breve til Holger Pedersen. (18) Fifty Years of Celtic Philology. The Presidential Address of the Modern Humanities Research Association read at University College, London, on 9 January 1976. Trykt i Modern Language Review. Vol. 71. Cambridge i976, p. XXIV. - (19) Nelson's Pillar i O'Connell Street: en dorisk søjle efter udkast af arkitekten William Wilkins ( $1778-1829)$ med en statue udført af billedhuggeren Thomas Kirk $(1777-1845)$, rejst ca. 18 i 1 i Sackville Street, som gaden dengang hed. Monumentet blev beskadiget ved en eksplosion i 1966 og derefter nedrevet. - (20) Danskerne invaderede Dublin i det 9. årh. og blev drevet ud af normannerne i170-71. - (21) The Royal Irish Academy blev grundlagt 1785 og flyttede til sin nuvarende bygning i 19 Dawson Street $185^{2}$. Dets bibliotek rummer i dag ca. 2500 irske håndskrifter, f.ex. Leabhar Breac fra ca. ${ }^{1} 4^{11}$, Leabhar na hUidre eller the Book of the Dun Cow fra 11.-12. ârh., the Book of Ballymote fra det tidlige ${ }_{15}$. årh. samt Annals of the Four Masters fra $163^{2-3} 3^{6}$ (22) The Society for the Preservation of the Irish Language blev stiftet 1876. - (23) De 2 sagahåndskrifter, Holger Pedersen søgte at skaffe sig i facsimileudgaver, må have 
varet Leabhar na hUidre (Dublin 1870) og the Book of Leinster (Dublin I880). Den ene af de store irske sagnkredse "the Ulster Cycle“ er overleveret bl.a. i disse to håndskrifter. The Book of Leinster indeholder også fortællinger, der hører til en anden af de irske sagnkredse, nemlig "the Fenian Cycle“. - (24) Dat. 14 Mount Pleasant Parade, Ranelagh, Dublin. 15. Avgust ${ }_{1} 895$ - - (25) Sandsynligvis Douglas Hyde: Leabhar Sgeulaigheachta. Dublin 1889 . Jf. samme: A Literary History of Ireland. New ed. with an Introduction by Brian O Cuív. London 1980 , p. XV. - (26) Maxwell Henry Close (1822-1903). - (27) Robert Atkinson (1834-1908). - (28) Dat. Dublin d. 27. Avgust 1895. - (29) Letters of W. B. Yeats, ed. by Allan Wade. New York 1955, p. 268. (30) Optrykt flere gange, f.ex. i igı I, samt iJ. M. Synge: Collected Works. Vol. I-IV. Oxford $1962-68$, og som selvstændig publikation: The Aran Islands, ed. by R. Skelton. Oxford 1979. I det følgende er citaterne fra udgaven: The Aran Islands with drawings by Jack B. Yeats. Dublin 191 . - (31) Synge karakteriserer dem som „the long-legged pigs“. (Aran Islands (30), p. 3). - (32) Jf. Synge: „As the fishermen came in and out of the public-house underneath my room, I could hear through the broken panes that a number of them still used the Gaelic, though it seems to be falling out of use among the younger people of this village." (Aran Islands (30), p. 3). - (33) Dat. The Atlantic Hotel, Aran Isles (Aranmore) co. Galway. Irland. 2. Sept. 1895. - (34) Aran Islands (30), p. I. - (35) Arthur Symons: Cities and Sea-coasts and Islands. London 1918, p. 309. - (36) Aran Islands (30), p. 2. - (37) Jf. Synge's skildring af, hvorledes han på en tur med Martin/Mourteen stedse måtte løfte ham „over the low walls he is too shaky to climb." (Aran Islands (30), p. 132). - (38) Symons (35) p. 3 10 opgiver øens samlede befolkning til zooo. - (39) Teampull Benen el. Bheanain. - (40) St. Enda's Church. (41) Sandsynligvis D. Hyde: Leabhar Sgeulaigheachta (25). - (42) Holger Pedersens utilfredshed med Marc har han også givet udtryk for i sin anmeldelse i Indogermanische Forschungen, Anzeiger Bd. XI. Strassbourg 1900, p. 108-1 I, af N. F. Finck's Die araner Mundart. Marburg 1899 , hvor han beklager, at dennes hovedmeddeler har varet den ideligt skolemestererende Marc O'Flaherty. Et forhold han allerede kommer ind på i et brev fra Aran til prof. Herman Møller (1850-1923), dat. 14.10.1895. Han skildrer sin rejse og nævner, at han i Dublin har hørt, at der skulle vare en „other German“ på Aran. Først da han er nået til Aran, opdager han, at det er N. F. Finck, som netop har forladt øen. Han fremhaver, at dersom Marc, der var blevet rost til skyerne af Finck, har været dennes eneste kilde, må hans materiale være „af en meget tvivlsom Værdi; det kan ikke indeholde stort mere end hvad man bedre og billigere kan lare i Dublin“, da Marc, som Holger Pedersen opdager, til trods for at Finck også havde indskærpet ham, at han ønskede at kende de virkelig talte former, „systematisk har gennemfort et Slags „dannet Sprog“" med en svag Aran-Farve." $\left(\mathrm{NkS}_{4626,}{ }^{\circ}\right)$. - (43) Dat. Atlantic Hotel 6/10 1895. - (44) Indogermanische Forschungen (42) p. I 10; „... mein Hauptgewährsmann, der beste Märchenerzähler auf der Insel, ein 7 rjähriger Bauer... war erst nach langen Dressur für meine Zwecke brauchbar; anfangs war er ganz ausser Stande, auch nur einen einzigen Satz zu diktieren; nachdem er aber von mir entdeckt und dressiert worden war, ist er auch von anderen benutz worden, wie aus der hübschen, irisch geschriebenen Schilderung Fáinne an lae 19. November 1898 S. 154 hervorgeht." - 
(45) NkS 2718, fol. kapsel 15. - (46) Aran Islands (30), p. 3. - (47) Aran Islands (30), p. 12. - (48) Aran Islands (30), p. 132. - (49) Cities and Sea-coasts and Islands (35), p. $3_{18-20 .}$ - (50) Om Ussings afsked, se indledningen samt (10). - (51) Dat. Atlantic Hotel, 28.10.1895. - (52) Dat. Atlantic Hotel, 7/1 1895 - (53) NkS 2718, fol. kapsel I4. - (54) Otto Ribbeck ( $1827-1898$ ) klassisk filolog og fra 1877 professor i Leipzig. Han var tillige president for Königliche Sächsische Akademie der Wissenschaften, i hvis skriftrakke Holger Pedersens Albanische Texte (6) kom. - (55) Albanische Texte (6). - (56) Atlantic Hotel. Udat. - (57) Vilh. Thomsens (1842-1927) papirer i Det kgl. Bibliotek, NkS $4291,4^{\circ}$. - (58) Dat. Atlantic Hotel. Juleaften 1895. - (59) Dat. Atlantic Hotel, 27/12 1895. - (60) Da Holger Pedersen skulle tage fat på „Brødslidet“, var det ham i begyndelsen umuligt at få en stilling. Han søgte bl.a. ansættelse i gymnasieskolen og på Universitetsbiblioteket. Som gymnasielærer blev han vraget med den begrundelse, at han havde udmærkelse til embedsexamen, og på biblioteket afviste den daværende overbibliotekar ham på grund af hans videnskabelige studier, thi overbibliotekaren mente ikke, det passede sig for en biblioteksmand at beskaftige sig med sligt! - Brev til Ussing, dat. 16. Juni 1897 . (NkS 2718 , fol. kapsel 42). - (61) Dat. 12. Januar 1896. (62) Atkinson har skrevet flere afhandlinger om irsk. Her er der nok tale om hans Irish Lexicography: an Introductory Lecture. Dublin 1881, og On Irish Metric. An Inaugural Lecture on Celtic Philology. Dublin ${ }_{1} 88_{4}$. Den kymriske er det umiddelbart lettere at indkredse, det må dreje sig om On the Use of the Subjunctive Mood in Welsh, i: Transactions of the Royal Irish Academy, 1894. Hans indsats inden for koptiske studier synes at bestå af to indlæg i Proceedings of the Royal Irish Academy, 3. ser. Vol. III. 1893, p. 24 og 225. - (63) J. O. Russell: Recent Changes made in Scotch Gaelic, i: Revue celtique. Vol. 16. Paris 1895, p. 208-11. - (64) I.4.1896 blev Ussing efterfulgt af prof., dr. jur. Jul. Lassen i embedet som regensprovst, jvf. Aarbog for Kjøbenhavns Universitet (10) p. I04-05. - (65) Dat. Dublin, d. 21. Januar 1896. - (66) Selvbiografi (2). Endvidere skriver han $i$ et brev til Vilh. Thomsen, dat. 28.7.1913, om sine forelæsninger i Dublin: ,Jeg opholder mig for Tiden i Irland, hvor jeg ifølge mit to År gamle Lefte holder Forelæsninger ved "School of Irish Learning“ to Timer hver Dag undtagen Lördag, fra d. 14. Juli til d. 8. Avgust. Jeg har meget Arbejde, men gode Tilhørere, deriblandt adskillige, hvis Navn allerede er kendt på den keltiske Filologis Område (Professor Bergin, R. J. Best, Edward Gwynn, Tomás O'Máille, J. Fraser, J. H. Lloyd, Professor Calder, Miss Eleanor Hull).“ (NkS 4291, $\left.4^{\circ}\right)$. - (67) Brev dat. 7. Sept. 1935. NkS 2718, fol. Afd. X, kapsel 39 . 